

\section{DISCLAIMER}

This report was prepared as an account of work sponsored by an agency of the United States Government. Neither the United States Government nor any agency Thereof, nor any of their employees, makes any warranty, express or implied, or assumes any legal liability or responsibility for the accuracy, completeness, or usefulness of any information, apparatus, product, or process disclosed, or represents that its use would not infringe privately owned rights. Reference herein to any specific commercial product, process, or service by trade name, trademark, manufacturer, or otherwise does not necessarily constitute or imply its endorsement, recommendation, or favoring by the United States Government or any agency thereof. The views and opinions of authors expressed herein do not necessarily state or reflect those of the United States Government or any agency thereof. 


\section{DISCLAIMER}

Portions of this document may be illegible in electronic image products. Images are produced from the best available original document. 


\title{
SOURCES OF INTERNAL HYDRIDING IN UNIRRADIATED THORIA-FUELED ZIRCALOY RODS \\ (LWBR Development Program)
}

\section{J. C. Clayton}

February 1979

Contract No. EY-76-C-11-0014

\author{
Printed in the United States of America \\ Available from the \\ National Terhnical Information Service \\ U. S. Department of Commerce \\ 5285 Port Royal Road \\ Springfield, Virginia 22151
}

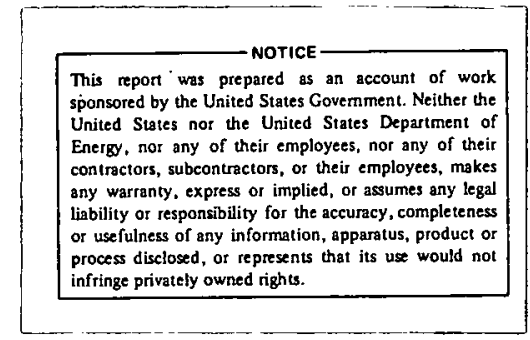

\section{NOTE}

This document is an interim memorandum prepared primarily for internal reference and does not represent a final expression of the opinion of Westinghouse. When this memorandum is distributed externally, it is with the express understanding that Westinghouse makes no representation as to completeness, accuracy, or usability of information contained therein.

\section{BETTIS ATOMIC POWER ILABORATORY \\ WEST MIFFLIN, PENNSYLVANIA}

Operated for the U. S. Department of Energy by WESTINGHOUSE ELECTRIC CORPORATTON 
This report was prepared as an account of work sponsored by the United States Government. Neither the United States nor the United States Department. of Energy, nor any of their employees, nor any of their contractors, subcontractors, or their employees, makes any warranty, cxpre3s or implied, or assumes any legal liability or responsibility for the accuracy, completeness or usefulness of any information, apparatus, product or process disclosed, or represents that its use would not infringe privately owned rights. 


\section{FOREWORD}

The Shippingport Atomic Power Station located in Shippingport, Pennsylvania was the first large-scale, central-station nuclear power plant in the United States and the first plant of such size in the world operated solely to produce electric power. This program was started in 1953 to confirm the practical application of nuclear power for large-scale electric power generation. It has provided much of the technology being used for design and operation of the commercial, central-station nuclear power plants now in use.

Subsequent to development and successful operation of the Pressurized Water Reactor in the DOE-owned reactor plant at the Shippingport Atomic Power Station, the Atomic Energy Commission in 1965 undertook a research and development program to design and build a Light Water Breeder Reactor core for operation in the Shippingport Station.

The objective of the Light Water Breeder Reactor (LWBR) program has been to develop a techriulogy that would significant.ly improve the utilization of the nation's nuclear fuel resources employing the well-established water reactor technology. To achieve this objective, work has been directed toward analysis, design, component tests, and fabrication of a water-cooled, thorium oxide fuel cycle breeder reactor for installation and operation at the Shippingport Station. The LWBR core started operation in the Shippingport Station in the Fall of 1977 and is expected to be operated for about 3 to 4 years. At the end of this period, the core will be removed and the spent fuel shipped to the Naval Reactors Expended Core Facility for a detailed examination to verify core performance including an evaluation of breeding characteristics.

In 1.976, with fabrication of the Shippingport LWBR core nearing completion, the Energy Research and Development Administration established the Advanced Water Breeder Applications (AWBA) program to develop and disseminate technical information which would assist U. S. industry in evaluating the LWBR concept for commercial-scale applications. The program will explore:some of the problems that would be faced by industry in adapting technology confirmed in the LWBR program. Information to be developed includes concepts for commercial-scale prebreeder cores which would produce uranium-233 for light water breeder cores while producing electric power, improvements for breeder cores based on the technology developed to fabricate and operate the Shippingport LWBR core, and other information and technology to aid in evaluating commercial-scale application of the LWBR concept. 


\section{FOREWORD (Cont)}

All three development programs (Pressurized Water Reactor, Light Water Breeder Reactor, and Advanced Water Breeder Applications) have been administered by the Division of Naval. Reactors with the goal of developing practical improvements in the utilization of nuclear fuel resources for generation of electrical energy using water-cooled nuclear reactors.

Technical information developed under the Shippingport, LWBR, and AWBA programs has been and will continue to be published in technical memoranda, one of which is this present report. 


\section{$\underline{\text { Page }}$}

I. INTRODUCTION

A. Purpose 1

B. Background 2

C. Previous Studies . . 3

1. Gas Release । 3

2. Hydrogen Pickup in Internal Cladding Surface 3

3. Hydrogen Permeation of Zircaloy Surface Films $\cdot 3$

II. EXPERTMEN'IAL. PROCEDURES $\quad$. 4

A. Miniature Rods and Coupons . 5

1. Hydriding of Zircaloy-4 5

$\begin{array}{ll}\text { a. Materials } & 5 \\ \text { b. Hydriding Apparatus } & 5 \\ \text { c. Hydrogen Measurements } & 5\end{array}$

2. Water Vapor Uxidation of Zircaloy-4 $\quad 6$

a. Materials 6

b. Oxidation Procedure 6

3. Process Control Samples 6

B. Full-Size Rods ․ . $\quad 7$

1. Moisture Content of Fuel 7

2. Gas Release from Fuel 8

3. Gas Release from Plenum Springs 8

4. Gas Release from Fuel Rods 9

III. RESULTS AND DISCUSSTION

A. Miniature R̈od̄s and Coupons 9

1. Low-Temperature, Low-Pressure Hydriding of Zircaloy-4 9

$\begin{array}{lr}\text { a. Zircaloy Coupons } & 9 \\ \text { b. Zircaloy Rods } & 10 \\ \text { c. Scratched Surfaces } & 11\end{array}$

2. Water Vapor Oxidation and Hydriding 11

3. Process Control Samples 13 : 
B. Full-Size Rods

1. Gas Release from Fuel

a. Moisture Pickup

b. Total Gases Released

2. Gas Release from Plenum Springs

3. Gas Release from Fuel. Rods

4. Internal Rod Surface Studies

IV. SUMMARY OF RESULTS

A. Miniature Zircaloy Rods and Coupons

B. Fuij-Siz.e 7.ircaloy Rode

1. $\mathrm{ThO}_{2}$ Fuel Pellets

2. Inconel Alloy $\mathrm{X}-750$ Plenum Springs

3. Preproduction Fuel Rods

VI. CONCLUSIONS

2 . Zircaloy-4 Tubing Properties

3 Hydroger-Reacted Lircaloy-4 Coupons

4 Hydrogen-Reacted "Zircaloy-4 Coupons

$5 \quad$ Hydrogen-Reacted Seed Rods 
10 Seed Rod Process Control Samples

11 Moisture Contents of NLO Thoria Powders

12 Methods of Achieving Humidity Conditions for Thoria Pellet Moisture Adsorption Experiments

13 . Moisture Content of $\mathrm{ThO}_{2}$ Reflector Pellets

.14 Low-Temperature Extractions: Reflector $\mathrm{ThO}_{2}$ Production Pellets

15 Low-Temperature Extractions: Reflector Inconel Alloy X-750 Plenum Springs

16 Mass Spectrometric Analyses of Preproduction Fuel Rod Internal Atmosphere

18 Comparison of Limits on Total Hydrogen in LWBR Fuel Rods With Hydride Failures Boundary

\section{LIST OF FIGURES}

Sectioned Miniature Blanket Rods

4 Scratched, Hydrided Curved Zircaloy Coupons

5 Moisture Content of $\mathrm{ThO}_{2}$ Reflector Pellets

6 Internal Hydriding Failure Boundary as a Function of Moisture Concentration 
The low-temperature $\left(\leq 550^{\circ} \mathrm{C}\right)$, low-pressure ( $\leq 36$ torr) hydrogen absorption characteristics of specific types of Zircaloy-4 internal cladding surfaces (pickled, machined and welded) were investigated. The highest hydrogen contents were found at the machined and abraded surfaces. Although the pickled surface film on Zircaloy-4 retarded hydrogen pickup, especially at lower temperatures $\left(\leq 400^{\circ} \mathrm{C}\right)$ and very low hydrogen pressures ( $\leq 3.5$ torr), some hydrogen was absorbed through the film even under these conditions. More hydrogen penetrated the pickled surfaces at higher temperatures and pressures. The pickled surfaces absorbed the hydrogen uniformly and without localization even with some film imperfections present. Little hydriding occurred when etched and welded Zircaloy-4 surfaces were exposed to water vapor at corrosion temperatures:

The source of the hydrogen is that left in the fuel pellets after vacuum-degassing, including moisture adsorhed during fuel loading, and hydrogenous contaminants on the metal cladding and hardware surfaces. High-density $\mathrm{ThO}_{2}$ pellets adsorbed moisture from the atmosphere and the amount of such moisture increased with increasing humidity and increasing time of exposure. The moisture adsorbed on the $\mathrm{ThO}_{2}$ pellet surfaces and internal cladding components was desorbed during the fuel rod corrosion tests and reacted with the Zircaloy-4 cladding, forming hydrogen. Most of this chemically-formed hydrogen did not hydride the Zircaloy-4, but rather reacted with residual carbon and $\mathrm{CO}$ in the fuel to form various hydrocarbons.

SOURCES OF INTERNAL HYDRIDING IN UNIRRADIATED THORIA-FUELED ZIRCALOY RODS

(LWBR Development Program)

J. C. Clayton

\section{INTRODUCTION}

\section{A. Turpose}

Internal hydriding of the Zircaloy cladding has been a persistent cause of defects and occasional failures in water-cooled nuclear power reactors (References 1 through 4). The purpose of this study, conducted as part of the Light water Breeder Reactor (LWBR) Develupinienl Frogram, was to detcrmine the 
permeability of the internal Zircaloy cladding surfaces used in nuclear reactors to hydrogen outgassed from fuel pellets and internal metal components. The source of the hydrogen is that left in the fuel pellets after vacuum-degassing, including moisture adsorbed during fuel loading, and hydrogenous contaminants on the metal cladding and hardware surfaces. This hydrogen is then released during the fuel rod corrosion treatment and initial reactor operation. Information was obtained on the low-temperature $\left(\leq 550^{\circ} \mathrm{C}\right.$ ), low-pressure ( $\leq 36$ torr) hydrogen absorption characteristics of specific types of internal Zircaloy cladding surfaces (pickled, machined and welded). Localized hydrogen attack in scratches produced by oxide fuel rubbing against the Zircaloy cladding during assembly was also investigated.

\section{B. Background}

The LWBR core (Reference 4a) has a seed-blanket configuration consisting of an inner region containing 12 movable seed assemblies each surrounded hy $A$. blanket assembly. This inner region is surrounded by an outer reflector region containing 15 reflector modules. Each of these regions has a lattice of rodtype fuel elements arranged in a hexagonal pattern. These hexagonal modules are surrounded by an outer reflector region. In the seed and blanket rods, the fuel pellets are composed of mixed oxides of uranium-233 and thorium. In the reflector region and in sections at the top and bottom of the seed and blanket rods, the pellets are pure $\mathrm{ThO}_{2}$. The nominal pel let diameters are $0.25,0.47$ to 0.51 , and 0.74 inch for the seed, blanket and reflector pellets. An LWBR fuel rod consists of cylindrical thoria-hase fuel pel.7ets which are loaded into 9 -foot long Zircaloy tubes whose ends are capped and welded shut in a helium atmospherc. The completed tuel rod thus exhibits several types of internal zircaloy surfaces: the pickled tubing, the machined end plugs, and the top and bottom weld areas.

While the nominal internal atmosphere in many reactor fuel rods is pure helium at 1 atmosphere pressure, degradation of the heli.um atmosphere resulta both from fission gases released from the fuel during power operation and gaseous contaminants introduced during fabrication of the rods. Hydrogenous gaseous impurities can cause internal hydriding of the zircaloy cladding, leading to clad embrittlement, defect formation, and potential fuel rod failure. In addition, the impurity gases in the helium atmosphere can lower the thermal conductance of the t'uel-clad gap, raising the operatirg temperature of the fuel and, if present in appreciable quantities, can increase the internal pressure of the fuel rod. Because of these factors, the LWBR core was subjected to stringent controls on manufacturing procedures to minimize hydrogenous contaminants. 
1. Gas Release

Although most gas release measurements from $\mathrm{ThO}_{2}$ and $\mathrm{ThO}_{2}-\mathrm{UO}_{2}$ have been performed on powders, Smid has obtained gas release data on sintered seed-size pellets (Reference 5). Volatile gas release was investigated over the temperature range 800 to $2000^{\circ} \mathrm{C}$ using mass-spectrometric techniques. About 75 percent of the released hydrogen gas from $\mathrm{ThO}_{2}-\mathrm{UO}_{2}$ pellets was extracted at $1000^{\circ} \mathrm{C}$ and below; thermal exposure to $1200^{\circ} \mathrm{C}$ was necessary to release the remaining hydrogen gas. Temperature had a similar effect on the total gas; complete release was not attained until $1200^{\circ} \mathrm{C}$. Pure $\mathrm{ThO}_{2}$ pellets released more than 90 percent of the hydrogen gas at $1000^{\circ} \mathrm{C}$ but required higher temperatures for complete total gas release. Based on this work, all LWBR fuel pellets were vacuum-degassed for 3 to 4 hours at $1000^{\circ} \mathrm{C}$ after grinding and prior to loading into fuel rods. l'hese degassing conditions were sufficient to meet a specification of $1.5 \times 10^{-4} \mathrm{cc} / \mathrm{g}$ of residual hydrogen which was judged technically acceptable for fuel rod operation.

\section{Hydrogen Pickup in Internal Cladding Surfaces}

Susceptibility to hydriding has been found to be a major factor limiting the useful life of Zircaloy-clad fuel elements (References 1, 2, 3, 4 and 6). Internally generated failures have been traced to local hydriding as a result of contamination of the rod contents by hydrogenous materials (References 1,2 , 3, 4, 6 through 10). The most common contaminant is moisture, but organic residues (grease, pump oil, etc.) have caused excessive hydriding in some rods (References 4, 11 and 12). Since the total moisture pickup increases with increasing fuel pellet surface area and decreasing density, internal hydriding should be more prevalent in rods containing low-density and vibratory-compacted fuel (References 4, 7, 11 and 13). Pellet drying and hot-vacuum-degassing techniques have been applied as remedies for minimizing fuel rod moisture levels (References 1, 4, 13 and 14). In addition, several investigators have shown. that excessive hydriding in Zircaloy could not be produced with $\mathrm{H}_{2} \mathrm{O}$ additions alone, but only when a considerable quantity of $\mathrm{H}_{2}$ (References $8,15,16,17$ and 18) or a minimum quantity of HF (References 8 and 9 ) was present.

\section{Hydrogen Permeation of Zircaloy Surface Films}

The role of zirconium and Zircaloy surface treatments and surface films in hydrogen permeation has been investigated by several workers (References 18 through 26). After being abraded and immediately placed in a vacuum, Zircaloy-2 
surfaces absorbed hydrogen rapidly at $300^{\circ} \mathrm{C}$ (Reference 19). Hydride layers formed only when the Zircaloy surface had become saturated with hydrogen in solid solution. A transparent oxide film is readily formed on zirconium and the Zircaloys in air at room temperature (References 20 and 22). This room temperature $\mathrm{film}$ is somewhat resistant to hydrogen permeation at 150 to $300^{\circ} \mathrm{C}$, but permeation becomes rapid at 300 to $400^{\circ} \mathrm{C}$. Vacuum-annealing at 150 to $300^{\circ} \mathrm{C}$ increases the hydrogen uptake at $150^{\circ} \mathrm{C}$, possibly by decreasing the thickness of the oxide film barrier. Vacuum-annealing at higher temperatures $\left(\geq 400^{\circ} \mathrm{C}\right)$ dissolves the room temperature oxide film. Film dissolution and hydrogen absorption also increase with increasing time at temperature.

Chemical etching $\left(\mathrm{HNO}_{3} / \mathrm{HF}\right)$ zirconium and the 7ircaloys paseivatcc their surfaces towards hydrogen by forming transparent, highly-resistant oxide (or f'luoride) films (Rcferences 20, 2l, 22 and 27.). The pickled film is more hydrogen-resistant than the room temperature air film (References 20 through 2?). No reaction with hydrogen was observed for pickled surfaces at $150^{\circ} \mathrm{C}$; some hydrogen absorption occurred at 300 to $350^{\circ} \mathrm{C}$, but this required long induction times and high hydrogen pressures (References 19, 20 and 22). Raising the hydrogen reaction temperature to $400^{\circ} \mathrm{C}$ resulted in breakdown of the chemical film. Vacuum-annealing at $\geq 400^{\circ} \mathrm{C}$ also tended to destroy the chemical film (References 21 through 23). When the chemical film becomes permeable, the reaction with hydrogen can be either quite localized (References 19 throngh ??) nx uniform over the whole surface (References 23 and 26).

Less information exists on the surface properties of welded zirconium (References 18, 28 and 29). Corrosive attack is generally restricted to the surface layer of the weld area but the corrosion resistance of zirconium as affected by heat-treatment may vary widely (References 28 arid ?9).

In summary, the reaction of hydrogen with zirconium and the Zircaloys depends on surface condition, temperature, time at temperature and hydrogen pressure. Protective surface films are rendered permeable to hydrogen by vacuum-annealing. Films formed by pickling are more impermeable to hydrogen than room temperature air oxidation films.

\section{EXPERIMENTAL PROCEDURES}

Hydrogen uptake measurements were f'irst performed on Zircaloy-4 coupons and miniature rods as a function of temperature $\left(\leq 550^{\circ} \mathrm{C}\right)$ and initial hydrogen pressure. The sources of hydrogen in full-size preproduction LWBR Zircaloy-4 thoria-fueled rods were also examined. 
A. Miniature Rods and Coupons

1. Hydriding of Zircaloy-4

a. Materials

(1) Coupons. The coupons used in this study were made from Zircaloy-4 ingots which were arc-melted, forged, and hot-rolled at $800^{\circ} \mathrm{C}$ to a $0.25-\mathrm{cm}$ thick sheet. Welding tabs were attached to the rolled strip from one ingot and the sheet was converted to weld metal by arc-welding in helium. (TIG). Coupons $(2.54 \mathrm{~cm} \times 1.37 \mathrm{~cm} \times 0.075 \mathrm{~cm})$ were machined directly from the as-rolled and welded.sheets. Chemical analyses of coupons taken from the as-rolled strip are given in Table 1 .

Chemically-filmed surfaces were obtained by pickling in 55 percent $\mathrm{H}_{2} \mathrm{O}, 40$ percent $\mathrm{HNO}_{3}$, and 5 percent $\mathrm{HF}$ for two minutes followed by rinsing in iced cold distilled water for $1 / 2$ to 1 hour, in hot $\left(85^{\circ} \mathrm{C}\right)$ distilled water for 5 minutes and finally in isopropyl alcohol.

(2) Tubing and End Caps. Both seed and blanket tubing sections were used for fabricating miniature Zircaloy-4 unfueled LWBR rods. The tubing properties are listed in Table 2. The end caps were made from an ingot which was forged, extruded, swaged, centerless-ground and pickled to final size.

The end caps were welded onto the tubing sections in a helium atmosphere. The welded rods were leak-tested, vapor-blasted, etched and corrosion-tested in ammoniated water for 3.5 days at $343^{\circ} \mathrm{C}\left(650^{\circ} \mathrm{F}, 9.8\right.$ to $10.2 \mathrm{pH})$. Brass cylinders were used as fillers to prevent the Zircaloy-4 rods from collapsing on corrosion-testing. The pickled and corrosion-tested rods are shown in Figure 1.

b. Hydriding. Apparatus. A high-vacuum ( $5 \times 10^{-7}$ torr dynamic vacuum) glass apparatus was used for hydriding the Zircaloy-4 specimens. The system had an ionization gage for low-pressure readings, a Pirani gauge for measuring pressure changes between $10^{-3}$ and 3.5 torr, and an absolute pressure gauge (Wallace and Tiernan) for measurements in the higher pressure ranges up to 100 torr. A tube of zirconium hydride attached to the system was used to generate hydrogen.

c: Hydrogen Measurements. The analytical technique used for measuring the hydrogen content of the Zircaloy-4 samples was a manometric vacuum extraction method. The procedure consisted of collecting the gases evolved by vacuum extraction at $1300^{\circ} \mathrm{C}$, separating hydrogen gas by diffusion through a palladium disc, and manometrically determining the hydrogen content. This was supplemented by metallographic analyses of the hydrogen-reacted samples. 


\section{Water Vapor Oxidation of Zircaloy-4}

a. Materials. Two specimens of Zircaloy-4 tubing were exposed for one week at corrosion temperatures $\left(343^{\circ} \mathrm{C}\right.$ and $\left.371^{\circ} \mathrm{C}\right)$ to atmospheres of helium with controlled amounts of water vapor. The tubing consisted of 1.95-inch lengths of seed-size Zircaloy-4. Initial hydrogen analyses were from 10.5 to $12 \mathrm{ppm}$. An end-cap, $1 / 2$ inch long, was welded to one end of each of these short lengths of tubing. The outside diameter of the tubing was 0.307 inch; wall thickness was 0.025 inch.

b. Oxidation Procedure. The sections of Zircaloy tubing were placed in quartz bulbs together with, and immediately adjacent to, boats containing a twophase mixture of calcium oxide and calcium hydroxide. The $\mathrm{CaO}-\mathrm{Ca}(\mathrm{OH})_{2}$ mixture is a convenient means of maintaining a constant, continunus partial pressure of water. The equilibrium partial pressure of water vapor over this mixture is such that (Reference 30):

$$
\text { In } \mathrm{P}(\text { torr })=19.4646-\frac{10645.01}{\mathrm{~T}}
$$

where $T$ is temperature in ${ }^{\circ} \mathrm{K}$. At $343^{\circ} \mathrm{C}\left(616^{\circ} \mathrm{K}\right)$ the partial pressure is held at 9 torr; at $371^{\circ} \mathrm{C}\left(644^{\circ} \mathrm{K}\right)$ it is 19 torr.

The quartz bulbs were twice evacuated and backfilled with helium before being sealed. At the end of the heating run, x-ray diffraction confirmed that $\mathrm{CaO}$ and $\mathrm{Ca}(\mathrm{OH})_{2}$ were still present in the boats. It is therefore reasonable to assume that the two phases were present throughout the heating run, and that the equilibrium vapor pressure of water was closely and rnntinuously maintained.

\section{Process Control Samples}

Four 20-inch long seed rod process control samples were fabricated. Prior to evacuation for seal welding of the second enclosure, approximately $0.3 \mathrm{mg}$ of black particulate matter, which had heen scraped from the interior walls of a fuel pellet vacuum-degassing furnace, was introduced into the open end of a. seed rod. Similarly, approximately $0.2 \mathrm{ml}$ of mechanica.l va.cum pump oil was injected into the open end of a second seed rod. To prevent loss of the added contaminants during subsequent evacuation of the weld chamber, the open ends of these two rods were loosely plugged. A second set of process control rods was fabricated with the ends open, and sealed in the cleaned condition by core reference procedures. This set was designed to serve as control samples. 
Following seal welding, the rods were vapor-blasted, pickled, leak-tested, and subjected to the LWBR fuel rod core reference corrosion test of 3.5 days at $343^{\circ} \mathrm{C}\left(650^{\circ} \mathrm{F}\right)$. The corrosion-tested rods were punctured and the contained gases were collected. Mass spectrometric analyses were performed on the gases removed from the rods. The rods were then machined to remove the welded endclosures and hardware. The cladding tubes were slit axially to expose the interior surfaces for visual examination. Half gram samples were then taken from the top, center and bottom of the slit cladding tubes for metallographic hydride examination and hydrogen analyses.

\section{B. Full-Size Rods}

1. Moisture Content of Fuel

Two experimental techniques were used to measure the amount of moisture adsorbed by vacuum-degassed $\mathrm{ThO}_{2}$ pellets. In the first approach, the procedure used in Reference 5 was adapted and modified. To increase the quantity of gas and thus improve the sensitivity of the mass spectrometric analytical technique, 15 pellets rather than a single pellet were sampled. After exposure lo various humidity conditions, each group of 15 pellets was placed in a vacuum-annealing apparatus, which was pumped at room temperature to a residual pressure of 10 microns, a pressure equivalent to that. in an LWBR fuel rod prior to helium backfilling and final welding. Vacuum-annealing was then conducted for 4-hour periods at two temperatures: $350^{\circ} \mathrm{C}$, representative of the corrosion temperature of the fuel rod; and a significantly higher temperature of $700^{\circ} \mathrm{C}$. Previous studies (Reference 5) experimentally established that the major portion of the gas evolved from thoria-base pellets at temperatures $\geq 1000^{\circ} \mathrm{C}$ was released within 5 minutes. The water vapor released on vacuum-annealing was trapped in a liquid nitrogen-cooled bulb and measured by mass spectrometry. A set of freshly degassed pellets was also annealed as a blank since each group of pellets received about a 30-minute exposure to laboratory air during handling.

The second experimental approach used a direct chemical method ("Moisture Analyzer"). In this technique, the oxide sample is heated in flowing argon at temperatures up to $1000^{\circ} \mathrm{C}$. The evolved water vapor is conducted by the argon gas to a hygroscopic layer of $\mathrm{P}_{2} \mathrm{O}_{5}$ which quantitatively adsorbs the water vapor. Dry $\mathrm{P}_{2} \mathrm{O}_{5}$ is a poor electrical conductor but water renders the $\mathrm{P}_{2} \mathrm{O}_{5}$ film electrically conductive. The water is then quantitatively electrolyzed to hydrogen 
and oxygen. The electrolysis current serves as a direct indication of water content. The amount of moisture as a function of temperature can also be recorded. Although the apparatus was designed for and is best suited for powder samples, it was modified to accommodate $\mathrm{ThO}_{2}$ pellets.

\section{Gas Release from Fuel}

The vacuum extraction apparatus used to study moisture pickup on $\mathrm{ThO}_{2}$ pellets was also adapted for measuring their total gas contents. Groups of 15 centerless-ground reflector $\mathrm{ThO}_{2}$ production pellets were placed in the vacuumannealing apparatus which was evacuated at room temperature to a residual pressure of less than 1 micron. Vacuum-annealing was then conducted at temperatures up to $800^{\circ} \mathrm{C}$. The volatiles released nn vacuum-anncaling were firsl pumped through a liquid nitrogen-cooled bulb to trap the condensible vapors and the residual gases were collected in a second bulb at room temperature. The gas contents of the collection bulbs were analyzed by mass spectrometry, Cuntrol hianks were run in all cases, and had gas contents from 10 to 15 percent of the gas released from the $\mathrm{ThO}_{2}$.

Some anneals were performed in a combination vacuum extraction-mass spectrometer residual gas analyzer. Although this apparatus was capable of testing only 1 reflector peliet at a time, gas release measurements up to $1600^{\circ} \mathrm{C}$ could be obtained.

Finally, groups of 10 seed $\mathrm{ThO}_{2}$ production pellets were equilibrated with helium at temperatures between room temperature and $500^{\circ} \mathrm{C}$. At various times, aliquots of the helium atmosphere were examined by gas chromatography. A Bendix Series 2200 laboratory chromatograph was used to detect and analy'ze the evolved gases. Both thermal conductivity and flame ionization detectors were employed; the latter especially sensitive for hydrocarbon analyses.

\section{Gas Release from Plenum Springs}

The low-temperature vacuum extraction apparatus was also used for the measuremert of the gases evolved on heating reflector rod Inconel Alloy X-750 plenum springs at temperatures up to $700^{\circ} \mathrm{C}$. After an alcohol and a hot detergent scrubbing, the Inconel Alloy $\mathrm{X}-750$ springs were thoroughly rinsed in deionized water and dried in flowing nitrogen. The dried springs were individually heat-sealed in id length of polyethylene tubing and stored for several weeks. The springs were then removed from their polyethylene containers, transferred to a vacuum oven, dried for 1 hour at $110^{\circ} \mathrm{C}$, and stored under vacuum at room temperature until ready for loading into the gas extraction apparatus. 


\section{Gas Release from Fucl Rods}

Twenty preproduction LWBR fuel rods were punctured in a vacuum facility and their contained gases analyzed by mass spectrometry. The puncturing and sampling were uniform for all rods, and corrections were made for any gaseous impurity background in the analysis system. The rods included both as-fabricated and corrosion-tested seed, blanket and reflector types. The rods contained $\mathrm{ThO}_{2}$, $\mathrm{ThO}_{2}-\mathrm{UO}_{2}$, stainless steel and copper pellets.

Eight of the corrosion-tested rods were machined to remove the welded endclosures, internal hardware and fuel pellets. The cladding tubes were then split axially to expose their interior surfaces for visual examination. Representative clad samples were then taken for scanning electron microscopic observation, electron fluorescence analyses, metallographic hydride examination and hydroger analyses.

\section{RESULTS AND DISCUSSION}

\section{A. Miniature Rods and Coupons}

1. Low-Temperature, Low-Pressure Hydriding of Zircaloy-4

The experimental effort emphasized the following:

a. A comparison of the low-temperature $\left(\leq 550^{\circ} \mathrm{C}\right)$ hydrogen absorption characteristics of machined, pickled and welded Zircaloy surfaces;

b. The effect of a $3.5-$ day, $343^{\circ} \mathrm{C}$ heat treatment on the as-pickled surface film; and

c. The influence of scratches and other surface damage on the films.

Both Zircaloy coupons and rod-type specimens were studied. The samples were placed in a constant volume Sievert's apparatus modified so that the kinetics of hydrogen absorption could be followed at higher pressures and over a wide pressure range ( $10^{-3}$ to $10^{2}$ torr). The hydrogen-reacted samples were analyzed by manometric vacuum extraction and by metallographic techniques.

a. Zircaloy Coupons. The hydrogen absorption characteristics of abraded and pickled Zircaloy-4 coupons were first compared at $400^{\circ} \mathrm{C}$ and 1 torr of hydroeen. No significant reaction was observed for even abraded samples for exposure periods up to 1 week. Hydrogen absorption occurred at higher temperatures $\left(\geq 500^{\circ} \mathrm{C}\right)$ and greater hydrogen pressures ( 3.5 torr) as shown in Table 3. As would be expected, the pickled surface film retards hydrogen pickup, especially at low temperatures $\left(400^{\circ} \mathrm{C}\right.$ ) and low hydrogen pressures ( $\leq 3.5$ torr). However, some hydrogen is absorbed through the etched film even under these conditions. 
Hydrogen uptake measurements given in Table 4 show increased hydrogen penetration through the pickled surfaces at higher hydrogen pressures. More important, low-temperature $\left(360^{\circ} \mathrm{C}\right)$ vacuum-annealing renders the chemical film more permeable to hydrogen at these pressures. This has been confirmed by chemical and metallographic analyses. For example, the data of Table 4 show that, under an initial hydrogen pressure of 18.5 torr, prior low-temperature annealing of a pickled film increased the hydrogen content fivefold.

Hydriding experiments were performed on Zircaloy weld metal coupons and the measurements, listed in Table 4, also show similar effects of surface treatment; i.e., the high hydrogen pickup at machined surfaces was drastically reduced by a pickled surface film.

(v) Zircaluy Rods. Two seed and two blanket miniature unfueled rodo were prepared by reference production methods, including the standard corrosion testing ( 3.5 days at $343^{\circ} \mathrm{C}$ ) (Figure 1 ). The rods were machined in half to furnish a total of 8 specimens. Each rod sample was composed of a machined tubing edge, an inner-pickled tubing and end cap surface and a weld recion. The outer rod surface was protected by the oxide corrosion film.

The specimens were exposed to hydrogen in the Sievert's apparatus and hydrogen uptake was measured as a function of temperature ( 350 to $500^{\circ} \mathrm{C}$ ). and initial pressure ( 3.5 to 36 torr). Plots of hydrogen uptake versus time approxillaled parabolic curves and approached saturation after a l-wep expnsure poried. The hydrogen-reacted tubes were sectioned and analyzed by vacuum extraction ann by metallographic techniques. Some represcntative analyses are listed in Tables 5 and 6, and microstructures are illustratcd in Figure 2. The data arc in reasonable agreement with the hydrogen-reacted coupon samples. Although the highest hydrogen contents were found at the machined surfaces, medsurable amounts of hydrogen were consistently absorhed thrnigh the atched and anncaled films al all pressures. No localized hydrogen attiark milld bo detected nt. the welu regions.

One blanket rod was sectioned in quarters to furnish a machined end cap surface as well as a machined tubing edge. One specimen, illustrated in Figure 3, was vacuum-annealed ( 24 hours at $300^{\circ} \mathrm{C}$ ) and exposed to hydrogen ( $18.5 \mathrm{~mm}$ at $345^{\circ} \mathrm{C}$ ) in the Sievert's apparatus. The hydrogen was consumed in 20 minutes, and the tube was sectioned and analyzed for hydrogen content. Again, although the highest hydrogen contents ( 300 to $500 \mathrm{ppm}$ ) were found at the 
machined surfaces, some small amounts of additional hydrogen (20 ppm) were absorbed throughout the pickled and annealed film areas. No localized hydrogen attack was detected at the lightly-scratched regions on the pickled surface.

\section{(c) Scratched Surfaces. Although the permeability of Zircaloy to} hydrogen is markedly reduced by chemical etching, breaks in this protective surface film should result in rapid uptake in hydrogen at localized defected regions of the film, with the subsequent formation of hydride layers at these regions. The effect on hydrogen absorption of the presence of scratches on Zircaloy-4 was thus studied.

The hydrogen absorption characteristics of various types of scratches ( 0.5 to 5 mils deep) on pickled films on curved Zircaloy-4 specimens were compared at $400^{\circ} \mathrm{C}$. The scratches were made with a tungsten carbide scriber. 'l'he kinetics of hydrogen absorption were followed in the Sievert's apparatus and, as would be expected, the hydrogen uptake was greater in the scratched samples in all cases. In addition, as shown in Figure 4, heavy localized hydriding was observed visually when the scratched samples were hydrided in an oxygen-free atmosphere. The hydrogen uptake measurements, listed in Table 7, show that essentially all of the hydrogen is concentrated at the local areas of gross attack. However, whenever traces of oxygen were present, as inferred from the evidence of a blue tarnishing of the hydrogen-reacted Zircaloy sample and a slight increase (100 ppm) in oxygen content, hydrogen uptake, while greater than in the scratch-free specimens, was slower and more uniform with no visual evidence of localized attack. The data, given in Table 8, show that the scratched specimens had increased hydrogen absorption with the maximum amount of hydrogen being concentrated at the scratch. Other workers have observed some occasional slight surface oxidation on Zircaloy which retarded the absorption of hydrogen when their hydriding experiments were extended over long periods of time (Reference 3l).

\section{Water Vapor Oxidation and Hydriding}

$\Lambda$ s discussed in Section III.B.3, an analysis of the internal atmosphere of a preproduction LWBR thoria-fueled rod after corrosion-testing showed a significant amount of gaseous hydrogen, together with measurable quantities of hydrocarbons, in the helium used for filling the rod. It is concluded that moisture adsorbed on the thoria pellet surface and internal cladding components is desorbed during the corrosion test and reacts with the Zircaloy, forming 
hydrogen. Most of this chemically-formed hydrogen reacts with residual carbon and $\mathrm{CO}$ in the fuel to form various hydrocarbons, although some of the hydrogen may enter the cladding as a natural result of the corrosion reaction.

The amount of hydrogen measured in the corrosion-tested rod was $0.081 \mathrm{cc}$ at standard temperature and pressure. Since the void volume in the rod was 11.72 cc STP, the reported hydrogen therefore amounted to a partial pressure of 0.0069 atmosphere or 5.24 torr. If this amount of hydrogen is raised to a temperature $343^{\circ} \mathrm{C}\left(616^{\circ} \mathrm{K}\right)$, the partial pressure would increase to 11.8 torr. An experiment was performed to demonstrate that this quantity of water vapor in an atmosphere of helium would produce a significant amount of gaseous hydrogen by reaction with Zircaloy in the time and temperature of the conrnsion test (3.5 dayc at $343^{\circ} \mathrm{C}$ ), and furthermore, that a substantial portion of the generated liydrunen would remin in the gaseous state, rather than be absorbed in the Zircaloy as hydride.

Two seed-size sections of Zircaloy-4 tubing with welded end caps were exposed for 1 week at corrosion temperatures $\left(343^{\circ} \mathrm{C}\right.$ and $\left.371 .^{\circ} \mathrm{C}\right)$ to atmospheres of helium with controlled amounts of water vapor.* Weight gains of 16 and $55 \mathrm{mg} / \mathrm{dm}^{2}$ were measured for the 343 and $371^{\circ} \mathrm{C}$ samples, respectively, and a dark coating was observed on the metal after the l-week heat treatment. Table 9 shows the initial weights and weight gains for each of the tubes. If it is assumed that the entire weight gain was due to the uptake of oxygen formed by the reaction of zirconium with water vapor, then the two samples should have generated, respectively, 0.5 and $1.7 \mathrm{mg}$ of gaseous hydrogen; and if this hydrogen, in turn, had been entirely and uniformly absorbed by the tubing, the hydrogen content of the Zirculuy should have increased by 64 and $220 \mathrm{ppm}$, respectively.

Actual hydrogen increase, as determined by chemical analysis, was much less, and almost identical in the two snecimens. Samples worc takcn from the end lap, weld metal, and tubing wall of both tubes. A portion of the matcrial adjacent, to the cut end was also taken from tube S2-21M. Results are also given in Table 9.

The samples showed a gain of nnly 10 to $15 \mathrm{ppm}$ of hydrogen from che cullposition of 11 to $12 \mathrm{ppm}$ present before the heat treatment. Preferential hydrogen adsorption in welds or adjacent clad regions did not occur. Metallographic examination confirmed the chemical analyses by showing very low concentrations of hydride needles.

${ }^{*} \mathrm{CaO}-\mathrm{Ca}(\mathrm{OH})_{2}$ mixture as described in Section II.A.2. 
The lilerature contains scveral reports (References 8, 16, 17, 18 and 23) of workers who examined the oxidation and hydriding of alpha-zirconium by water vapor with various initial admixtures of hydrogen. Their work was done, for the most part, at temperatures higher than those used in this experiment. The results were, however, in agreement with those presented here. Little hydriding takes place in the presence of water vapor alone. Some hydrogen is absorbed if the initial atmosphere contained hydrogen; however, the amount is generally less than would be observed in the absence of water vapor. Some authors (References 8 and 17) attribute this to the oxygen generated by the water vapor which returns the oxide film towards stoichiometry and renders it less permeable to hydrogen.

The hydrogen dissolved in the Zircaloy amounted to approximately 20 percent of the total amount available to the $343^{\circ} \mathrm{C}$ sample, and 6 percent of the amount available to the $371^{\circ} \mathrm{C}$ sample. The balance remains as an impurity in the helium atmosphere and accounts for the free hydrogen gas detected in the corrosiontested preproduction rod.

The solution of 20 percent of the available hydrogen at $343^{\circ} \mathrm{C}$ is comparable to the results of corrosion-testing of Zircaloy-4 (Reference 18). In corrosion, the absorption of hydrogen in Zircaloy-4 runs from 15 to 25 percent of the amount generated. At $371^{\circ} \mathrm{C}$, the sample in the present experiment absorbed a lower proportion of the available hydrogen, and an almost identical absolute amount. Apparently, the reduced uptake of hydrogen at the higher temperature is due to the more effective protection of the Zircaloy afforded by the thicker oxide layer. It is likely that all of the hydrogen found in the Zircaloy entered during the earliest stages of the reaction.

\section{Process Control Samples}

During early LWBR development work, it was found that the thoria fuel pellet surfaces can become contaminated with hydrocarbon-containing materials during degassing and handling operations. The contamination sources included hydrocarbonaceous particulate matter formed during the degassing process itself (as a result of oil backstreaming associated with the operation of the vacuum system for the degassing furnace), as well as organic residues from transfer cans and polyethylene storage containers. Although these contaminants were eliminated by stringent process control and adherence to cleanliness standards, the extent of fuel rod atmosphere degradation and hydrogen pickup in the cladding resulting 
from a corrosion test of rods containing organic contaminants was determined. Thus, the effects of impurity volatilization and decomposition and subsequent reactions of the hydrogenous products with the internal rod surface were evaluated.

Seed process control rods were fabricated containing $0.3 \mathrm{mg}$ of black particulate matter* found in a degassing furnace in 1 rod and $0.2 \mathrm{ml}$ of vacuum pump oil in another rod, plus 2 uncontaminated control samples. All 4 rods were corrosion-tested for 3.5 days at $343^{\circ} \mathrm{C}\left(650^{\circ} \mathrm{F}\right)$. The atmospherc within the rods was analyzed for the presence of hydrogen and hydrocarbon gases, and the internal rod surfaces were examined visually and analyzed, using both chemical and metallographic techniques, for hydrogen pickup. The results are presented in Table 10. The internal rod hardware consisted of an Inconel plenum spring and a stainless steel spring-compression pellet, hut no fupl pellets. The water corrosion film on the outer surfaces of the test rods appeared norma.t. Inittle oxidation of the Inconel and stainless steel components was observed. However, the internal surfaces of the Zircaloy cladding tuhes displayed a chromatic variation in film appearance over the longitudinal axis with the thinnest film at the end which contained the stainless steel compression pellet. Chromatic variations in film appearance of the internal cladding tube surfaces at points of cont.a.t. with the plenum spring were also observed. In addition to the within-sample variation in film color along the tube length, a marked between-sample variation in color was noted (Table 10).

The high nitrogen content and blue internal. rlating film of the rod doped with pump oil ('lable 10) is indicative of incomplete evacuation of air prior to backfilling the weld box with helium. As described in Section II.A.3, constriction plugs were placed in the open ends of the doped rods to reduce losses of the contaminants during evacuation. The oxygen in the residual air reasten with the Zircaloy cladding internal surface during seal welding and corrosion testing to produce the blue film.

Table 10 shows that the helium atmosphere in the 2 control samples was degraded by 0.3 to 0.5 mole percent of aliphatic hydrocarbon gases (principally methane). The existence of methane series gases in these rods is explained by reaction of desorbed moisture from the metal surfaces with the Zircaloy cladding and subsequent reaction of the liberated hydrogen with carbonaceous residues on the metal surfaces. Table 10 also shows that the methane gas content of the

\footnotetext{
* Shown to be mainly hydrocarbonaceous by mass spectrometric analyses.
} 
doped sccd rods exceeded that of the control samples by factors of 2 (for the particulate matter) and 10 (for the vacuum pump oil), respectively. These results are not unexpected since previous mass spectrometric analyses demonstrated that both contaminants are rich in hydrocarbon gases. Finally, the hydrogen analyses of the Zircaloy cladding, also listed in Table 10, reveal no high hydrogen contents. Metallographic examination confirmed the chemical analyses by showing low uniform hydride concentrations.

B. Full-Size Rods

\section{Gas Release from Fuel}

As was noted in Section III.A.2, the presence of hydrogen and hydrocarbon gases in the atmosphere of corrosion-tested preproduction LWBR fuel rods was a.t.ributed to adsorbed moisture on the surface of the oxide fuel pellets and internal cladding components. Experiments were thus made to determine the effects of the ambient atmosphere, including humidity level and time of exposure, on degassed $\mathrm{ThO}_{2}$ fuel pellets.

\section{a. Moisture Pickup}

(1) Water Adsorption on $\mathrm{ThO}_{2}$ Powders. Experimental evidence exists that the amounts of both $\mathrm{H}_{2} \mathrm{O}$ and $\mathrm{CO}_{2}$, adsorbed on oxide fuels, increase with decreasing particle size and are thus directly related to surface adsorption (References 5, 32 and 33). Data on thoria powders showed that on a gas-free surface up to 3 layers of water can be adsorbed, but adsorption is generaliy less due to the presence of gases like $\mathrm{CO}_{2}$ (References 34 through 40). An evaluation was made relating the moisture content and the gas adsorption (BET) surface areas of 6 lots of LWBR production $\mathrm{ThO}_{2}$ powder. The thoria powders were manufactured by National Lead of Ohio (NLO) and the preparation process involved thorium oxalate precipitation and air calcination to $\mathrm{ThO}_{2}$ (Reference 41). The initial analyses for both water moisture content and surface area were performed at NLO around the time the powders were prepared at that location. The measurements are tabulated in Table $I l$ and show that the water contents of the "asfabricated" powders were equivalent to about 0.5 to 1.3 monomolecular layers of adsorption. Subsequent analyses of the powders, done at the Bettis Laboratory after the powders were exposed to ambient air for about 1 month, showed water adsorption equivalent to 1.4 to 2.3 monolayers (Table 11). The powder 
preparation and measurements were made over an 18-month period and represent a wide range of humidity conditions. The results substantiate the evidence concerning the extent of water adsorption by $\mathrm{ThO}_{2}$ powder.

(2) Water Adsorption on $\mathrm{ThO}_{2}$ Pellets. Experiments were made to measure the amount of moisture pickup by high-density, degassed $\mathrm{ThO}_{2}$ pellets. Groups of 15 centerless-ground, degassed reflector-size ThO 2 LWBR production pellets, with densities $\geq 95$ percent theoretical, were exposed to the various humidity conditions listed in Table 12. After exposure, each group of 15 pellets was vacuum-annealed for 4 hours and the released moisture measured by mass spectrometry as described in Section II.B.I.

The amounts of water vapor evolved as a function of humidity level, exposure time and annealing temperature are given in Table 13. The data show moisture adsorption on exposure to environments of' low humidities for long times and high humidities for short times. As would be expected, the amount of moisture adsorbed by the $\mathrm{ThO}_{2}$ pellets increased with increasing humidity and increasing time of exposure.

The amounts of moisture released from the production $\mathrm{ThO}_{2}$ reflector pellets stored under ambient and low-humidity conditions are in agreement with previous measurements on laboratory-prepared, seed-size $\mathrm{ThO}_{2}$ and $\mathrm{ThO}_{2}$-UO pellets (Reference 5). However, the moisture contents of the pellets that were exposed to 93-percent relative humidity are less than the values previously measured and reported in Reference 5. This could be due to differences in the "effective" pellet surface areas*. of the types of pellets used, or to variations in experimental techniques. In the work reported in Reference 5, high humidities were obtained by boiling water at different temperatures in a partial vacuum, and some of the liquid water could have been transferred to or condensed on the pellet surface. In the present work, the pellets were plareed in rinser cabinets containing saturated solutions of salts which give the desired humidity near room temperature; for example, $\left(\mathrm{NH}_{4}\right) \mathrm{H}_{2} \mathrm{PO}_{4}$ solution yielded a 93-percent relative humidity at 25 to $30^{\circ} \mathrm{C}$ (Table 12 ).

The $\mathrm{ThO}_{2}$ pellet moisture contents as a function of percent relative humidity for 24- to 96-hour exposure periods are plotted in Figure 5. Curves 5A. and $5 \mathrm{~F}$ show the experimental data. Curves 5B through 5E for intermediate exposures ( 32 to 60 hours) were obtained by interpolation.

* Lower densities and more open porosity result in a greater "effective" surface area. 
The manner in which the amount of moisture adsorbed by the thoria pellets at each humidity level varies with time is typical of general adsorption behavior in not being a linear function. Initially, the amount of adsorbed moisture increases relatively rapidly with time and then much more slowly as the thoria surface becomes covered with gas molecules. The empirical plots of adsorbed moisture versus time resemble Freundlich-type or "classical" adsorption isotherms, which are of the form:

$$
\mathrm{y}=\mathrm{kP}^{\mathrm{I} / \mathrm{m}}
$$

where $y$ is the volume of gas adsorbed per unit area, $P$ is the gas pressure, and $\mathrm{k}$ and $\mathrm{m}$ are empirical constants. This equation. is tested by plotting log $\mathrm{y}$ against $\log$ P. A straight line should result with slope equal to $1 / \mathrm{m}$ and ordinate intercept equal to $\log \mathrm{k}$. Such plots were constructed for the adsorption of moisture with time on thoria over a range of humidity levels. The requirements of Equation (2) were met satisfactorily at lower and intermediate relative humidities ( $\leq 70$ percent). At the higher humidities, the plotted points began to curve away from a straight linte.

The experimental points shown in Figure 5 for Tho 2 reflector pellets were computer-fitted to the equation:

$$
y=\left(4.409 \times 10^{-6} \mathrm{D}\right) \mathrm{P}\left(\frac{1}{I+0.1245 \mathrm{D}}\right)
$$

where

$$
\begin{aligned}
& \mathrm{y}=\text { volume of moisture absorbed on thoria, expressed in cc (STP)/g } \\
& D=\text { time, days } \\
& P=\text { partial pressure of water, torr. }
\end{aligned}
$$

The values of $P$ for 100-percent relative humidity are tabulated for various temperatures in standard reference works. Alternatively, they may be calculated by means of the empirical equation:

$$
P_{0}=2.2592 \exp (0.0600811 T)
$$

where

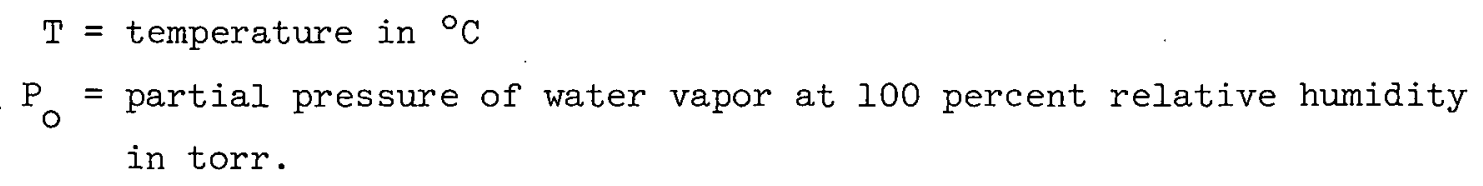


To find $P$, the quantity $P_{0}$ must be multiplied by the percent relative humidity divided by 100 .

The moisture adsorption data plotted in Figure 5 are based on the experiments in which water vapor is desorbed at $700^{\circ} \mathrm{C}$ over a 4 -hour period. Using an assumed activation energy for adsorption of 15,500 calories/mole (a reasonable value for this quantity of water vapor on solids (Reference 42)), it is calculated that essentially the same amount of desorption will occur during the $343^{\circ} \mathrm{C}\left(650^{\circ} \mathrm{F}\right), 3.5$-day corrosion test.

In a second experimental method, a set of three $\mathrm{ThO}_{2}$ pellets was heated in flowing argon at temperatures up to $1000^{\circ} \mathrm{C}$. The evolved water vapor was quantitatively adsorbed by $\mathrm{P}_{2} \mathrm{O}_{5}$ and recorded as a function of temperature. Mieasurements were made on degassed LWBK rețlector production bellist.s a.ft.pr exposure to several humidity levels (< 10, 28, 50 and 98 percent). In each case an appreciable amount of moisture was initially evolved at $75^{\circ} \mathrm{C}$ and the major fraction of the adsorbed water was released by $400^{\circ} \mathrm{C}$. Some moisture was retained up to $950^{\circ} \mathrm{C}$. The data confirmed the mass-spectrometric measurements in showing. that the amount of moisture adsorbed by the ${ }^{\prime \prime h} \mathrm{O}_{2}$ reflector pellets increased with increasing humidity and increasing time of exposure.

b. Total Gases Released. Groups of 15 centerless-ground reflector $\mathrm{ThO}_{2}$ production pellets, exposed to various ambient atmosphere conditions described in Table 14, were vacuum-annealed at temperatures up to $800^{\circ} \mathrm{C}$ and the evolved gases measured by mass spectrometry. The total gas release data, also given in Table 14, are self-consistent; i.e., most gas released by the non-degassed pellets ( $1 \times 10^{-3} \mathrm{cc} / \mathrm{g}$ ) and least by the degassed pellets with minimal atmospheric exposure $\left(0.2 \times 10^{-3} \mathrm{cc} / \mathrm{g}\right)$. The amount of moisture adsorbed by the ThO 2 pellets increased with increasing humidity. The major portion of the adsorbed water is released by $350^{\circ} \mathrm{C}$. The relatively high hydrocarbon values are qualified by the fact that these organics were often present in the background of the vacuumannealing apparatus itself.

A series of reflector $\mathrm{ThO}_{2}$ production pellets were vacuun-acgusised at higher temperatures ( 1800 and $2000^{\circ} \mathrm{C}$ ) to remove essentially all remnant gas before being subjected to various storage and exposure conditions. The pellets were then vacuum-annealed at $1600^{\circ} \mathrm{C}$ and the released gases measured in the residual gas analyzer. It was found that, although appreciable amounts of $\mathrm{CO}$ are consistently detected in the gases evolved from $\mathrm{ThO}_{2}$ pellets that are 
degassed at $1000^{\circ} \mathrm{C}$, no $\mathrm{CO}$ was detected in the pellets that were vacuum-annealed at $1800^{\circ}$ and $2000^{\circ} \mathrm{C}$. Hydrogen was the main constituent of the gases released from the pellets annealed at the higher temperatures; the other gases were hydrocarbons. As would be expected, the total gas contents of those pellets that were transferred directly from the annealing furnace to the residual gas analyzer were lower than those measured for pellets that had been exposed to ambient atmosphere or to longer storage times in a vacuum desiccator.

Groups of 10 seed $\mathrm{ThO}_{2}$ production pellets, that had been vacuum-degassed at $1000^{\circ} \mathrm{C}$ and then exposed to ambient air for several weeks, were equilibrated with helium at room temperature. A gas chromatograph sample was withdrawn after the helium had been in contact with the pellets for 18 hours. A total of 4 runs were made and, in all cases, no hydrocarbons were detected in the room temperature gas sample by the flame ionization detector, which is sensitive to hydrocarbons. Each group of pellets was then heated to over $500^{\circ} \mathrm{C}$ and, at various temperatures, aliquots of the helium atmosphere were examined. The thermal conductivity detertor showed no hydrogen-bearing gas except for water vapor. Significant amounts of methane $\left(\mathrm{CH}_{4}\right)$ and ethylene $\left(\mathrm{C}_{2} \mathrm{H}_{4}\right)$ were detected by flame ionization at temperatures around $300^{\circ} \mathrm{C}$ and above. Traces of high hydrocarbons were observed at the highest temperatiures. All of the residual hydrocarbons were driven off at 480 to $504^{\circ} \mathrm{C}$ in helium.

\section{Gas Release from Plenum Springs}

Three Inconel Alloy $\mathrm{X}-750$ reflector fuel rod plenum springs were individually vacuum-annealed at 350 and $700^{\circ} \mathrm{C}$ and the evolved gases measured by mass spectrometry. The gas release data are tabulated in Table 15. Most of the gases evolved at $350^{\circ} \mathrm{C}$ were condensibles; i.e., collected in a liquid nitrogencooled sontainer, and consisted of water vapor and $\mathrm{CO}_{2}$. At $700^{\circ} \mathrm{C}$, the evolved gases were mainly hydrogen and $\mathrm{CO}$. Vacuum-drying at $110^{\circ} \mathrm{C}$ did not appreciably reduce the amount of adsorbed moisture.

\section{Gas Release from Fuel Rods}

During the initial LWBR fuel rod fabrication development, 20 fuel rods were punctured and their gaseous atmosphere analyzed by mass spectrometry. The range of analyses for reflector, blanket and seed fuel rods are listed in Table 16. The purity of the atmosphere of the as-welded rods was high. The helium contents before corrosion-testing varied from 99.84 to 100.00 percent with, at most, only traces of hydrogen. The gaseous purity level is 
significantly degraded by corrosion-testing in all cases. Hydrogen and assorted hydrocarbons, mainly methane, constituted the major portion of the impurities in the atmosphere of the corrosion-tested rods. Similar results were found for the rods containing sintered metallic pellets.

The gas extraction data listed in Tables 14 and 15 show that the major volatiles released on heating both thoria fuel pellets and Inconel plenum springs are water vapor, hydrogen, $\mathrm{CO}$ and $\mathrm{CO}_{2}$. Water vapor readily reacts with Zircaloy, forming additional hydrogeń:

$$
\mathrm{Zr}+2 \mathrm{H}_{2} \mathrm{O} \longrightarrow \mathrm{ZrO}_{2}+2 \mathrm{H}_{2} \text {. }
$$

The reaction between hydrogen and any residual carbon in the fuel to form methane is thermodynamically favorable at corrosion temperaturee (05 percent complete):

$$
\mathrm{C}+? \mathrm{H}_{\mathrm{C}} \longrightarrow \mathrm{H}_{4}
$$

In addition, the reaction between carbon monoxide and hydrogen serves as a basis for the commercial production of very substantial amounts of hydrocarbons (Reference 43). The reactions occur at temperatures hetween 200 and $500^{\circ} \mathrm{C}$, and the reaction products range from methane to a complex mixture of higher hydrocarbons:

$$
\begin{gathered}
2 \mathrm{CO}+2 \mathrm{H}_{2} \longrightarrow \mathrm{CH}_{4}+\mathrm{CO}_{2} \\
\mathrm{CO}+3 \mathrm{H}_{2} \longrightarrow \mathrm{CH}_{4}+\mathrm{II}_{2} \mathrm{O} \\
\mathrm{nCO}+2 \mathrm{nH}_{2} \longrightarrow \mathrm{C}_{\mathrm{n}} \mathrm{II}_{2 \mathrm{n}} \mathrm{nH}_{2} \mathrm{O} \\
\mathrm{nCO}+(2 \mathrm{n}+1) \mathrm{H}_{2} \longrightarrow \mathrm{C}_{\mathrm{n}} \mathrm{H}_{2 \mathrm{n}+2}+\mathrm{nH}_{2} \mathrm{O} \\
12 \mathrm{CO}+3 \mathrm{H}_{2} \longrightarrow \mathrm{C}_{6} \mathrm{H}_{6}+6 \mathrm{CO}_{2} .
\end{gathered}
$$

The commercial processes use metallic catalysts and both zirconium and thoria have catalytic properties (References 39, 40 and 44). In-situ formation of hydrocarbons has been previously postulated to account for their presenre in the atmosphere of heated, unirradiated $\mathrm{UO}_{2}$ fuel rods (Reference 33).

It is thermodynamically unlikely that any methane or higher hydrocarbons in the $\mathrm{ThO}_{2}$ fuel pellets could survive such drastic temperature trentments as sintering at $1750^{\circ} \mathrm{C}$ and vacuum-annealing at $1000^{\circ} \mathrm{C}$. However, some hydrocarbon contaminants and moisture could be picked up from the atmosphere during pellet 
storage and rod loading. Contamination on the metal surfaces may be the result of remnant traces of lubricant (used during tubing fabrication), cleaning agents and moisture not removed by the heating procedure prior to rod assembly.

The two possible sources of hydrocarbon impurities, process contamination and in-situ formation, are not mutually exclusive and both sources may have contributed to the total quantity of organics.

\section{Internal Rod Surface Studies}

During visual examination of pickled preproduction reflector Zircaloy tubing, occasional "black spots" and "frosty areas" were observed on the inside surface. Chemical analyses, given in Table 17, show higher amounts of carbon and fluorine for the "bl.ack-spotted" and "frosty" regions, respectively, when comparcd with clear areas. Mass spectrometric analyses of the gases evolved on vacuum extraction, $\left(6\right.$ hours at $\left.370^{\circ} \mathrm{C}\right)$ showed that the gases released from each type of tubing were similar in composition, primarily hydrogen (60 to 80 percent) with the balance being hydrocarbons. The results indicate that the

"frosty areas" are pickling acid residues and the "black spots" are organic contaminants. Because of this, production tubing was carefully scrutinized by means of borescopic inspection to reject such type of tubing for core use.

A total of eight corrosion-tested preproduction seed, blanket and reflector fuel rods were slit for examination of internal clad surfaces. The typical tube displayed a series of interference colors on its inside surface near the plenum region with some occasional colored rings and damaged areas in the remainder of the rods. One blanket rod differed by having a continuous grey corrosion film over its entire inner surface. This rod had a high gaseous impurity level ( 1.50 percent organics; Table 16). Thorough SEM examinations and electron fluorescence analyses showed that no major surface contaminants were present and indicated that both the colored interference bands and grey corrosion areas are zirconium oxide. The internal zirconium oxide films are probably due to reaction with water vapor released from the fuel and internal metal hardware during corrosion-testing of the rod.

The cladding from each of the 8 fuel rods was sectioned in 4 to 8 different areas (colored, clear, damaged, undamaged surfaces) for chemical analyses and metallographic examination of their hydride contents. Although the cladding hydride concentration varied somewhat from rod to rod ( 15 to $25 \mathrm{ppm}$ ), the hydride 
contents of the colored bands and damaged surfaces were generally similar to that of the clear zones; i.e., no appreciable increase in hydride content can be attributed to the colored rings or damaged regions. Only in the blanket rod with a continuous grey corrosion film over most of its interior was a significant variation in hydrogen concentration found. Both mctallographic observation and chemical analyses showed higher hydrogen concentrations (30 to $43 \mathrm{ppm}$ ) in the heavy dark grey areas as compared to the lighter steel grey regions (24 to $28 \mathrm{ppm}$ ).

The machined end caps next to the fuel pellets were normal in appearance and hydrogen concentration in most of the fuel rods. However, some of the machined end plugs adjacent to the Inconel. p.enum springs had grey corrosion areas and higher hydrogen contents $(\sim 50 \mathrm{ppm})$.

IV. SUMMARY OF RESULTS

A. Miniature Zircaloy Rods and Coupons

1. Although the pickled surface film on Zircaloy retarded hydrogen pickup, especially at low temperatures $\left(100^{\circ} \mathrm{C}\right)$ and very low hydrogen pressures ( $\leq 3.5$ torr), some hydrogen was absorbed through the film even under these conditions.

2. More hydrogen penetrated the pickled surfaces at higher temperatures $\left(>400^{\circ} \mathrm{C}\right.$ ) and hydrogen pressures (>3.5 torr). Prinr inw-temperature vacuum-annealing rendered the chemical film more permeable to hydrogen.

3. The pickled surfaces absorbed the hydrogen uniformly and withnut. localization even with some film imperfections present. The hydrogen pickup was a function of temperature and pressure.

4. As would be expected, the highest hydrogen contents were found at the machined and abraded surfaces.

5. Heavy localized hydriding was produced in pickled Zircaloy surfaces by severely scratching the film.

6. Little hydriding occurred when pickled and welded Zircaloy surfaces wer expras to water vapor at corrosion temperatures ( 343 and $371^{\circ} \mathrm{C}$ ).

7. The internal atmospheres of corrosion-tested process control fuel rods containing organic additives were rich in hydrocarbon gases, but no high hydrogen contents were deterter in the zircaloy cladding. 


\section{B. Full-Size Zircaloy Rods}

1. $\mathrm{ThO}_{2}$ Fuel Pellets

a. Atmospheric moisture was adsorbed by high density $\mathrm{ThO}_{2}$ pellets and the amount of such moisture increased with increasing humidity and increasing time of exposure.

b. Initially, the amount of moisture adsorbed by the $\mathrm{ThO}_{2}$ pellets increased relatively rapidly with time and then much more slowly as the thoria surface became covered with gas molecules.

c. The adsorhed moisture versus time data were computer-fitted to a c].assical adsorption isotherm equation:

$$
\mathrm{y}=\mathrm{KDP} \mathrm{T}^{\mathrm{I} /(1+\mathrm{MD})}
$$

where $y$ is the value of moisture adsorbed on thoria, $D$ is time, $P$ is the partial pressure of water, and $K$ and $M$ are empirical. constants.

d. On heating Tho 2 pellets, an appreciable amount of moisture is initially evolved at $75^{\circ} \mathrm{C}$ and the major fraction of the adsorbed water is released by $400^{\circ} \mathrm{C}$. Some moisture is retained up to $950^{\circ} \mathrm{C}$.

e. The majority ( $\geq 85$ percent) of the gases evolved at $325^{\circ} \mathrm{C}$ from groups of degassed $\mathrm{ThO}_{2}$ pellets, that were exposed to high and low humidity levels, were condensibles and consisted of water vapor, $\mathrm{CO}_{2}$ and hydrocarbons. The amount of adsorbed moisture released by the $\mathrm{ThO}_{2}$ pellets increased with the higher humidity exposures. At $700^{\circ} \mathrm{C}$, the evolved gases were mainly hydrogen and $\mathrm{CO}$.

\section{Inconel Alloy $\mathrm{X}-750$ Plenum Springs}

Most of the gases evolved at $350^{\circ} \mathrm{C}$ from Tnconel reflector fuel rod plenum springs consisted of water vapor and $\mathrm{CO}_{2}$. At $700^{\circ} \mathrm{C}$, the evolved gases were principally hydrogen plus some $\mathrm{CO}$.

\section{Preproduction Fuel Rods}

a. The purity of the atmosphere of as-welded preproduction fuel rods was high ( 99.84 to 100.00 percent helium), but was degraded slightly by corrosion-testing.

b. Hydrogen and assorted hydrocarbons, mainly methane, constituted the major portion of the impurities in the atmosphere of the corrosion-tested preproduction fuel rods. 
c. Moisture adsorbed on the $\mathrm{ThO}_{\text {? }}$ pellet surface and internal cladding components was desorbed during the corrosion test and reacted with the Zircaloy, forming hydrogen. Most of this chemically-formed hydrogen reacted with residual carbon and $\mathrm{CO}$ in the fuel to form various hydrocarbons.

d. The hydrogen concentrations of various types of preproduction corrosion-tested zircaloy rods, including internally-filmed and damaged surfaces were similar to those of clear zones; $i . e .$, nc appreciable increase in hydride content was attributed to the colored rings or damaged regions.

\section{APPLICATION OF RESULTS}

The experimental findings of this study indicate that an effective way to avold any excessive internal rod hydriding is to minimize the hydrogenous materials in the fuel rod atmosphere by stringent controls on the manufacturing procedures. All LWBR production fuel pellets were vacuum-degassed for 3 to 4 hours at $1000^{\circ} \mathrm{C}$ and stored in a helium or vacuum atmosphere until. ready for loaking into fuel. rods. Randomly-selected pellet samples were given an additional vacuum extraction treatment at $1600^{\circ} \mathrm{C}$, and the evolved gases were measured and required to meet a product attribute limit. The residual gas limit was $\leq 12 \times 10^{-3} \mathrm{cc}$ of total gas, at standard temperature and pressure, per gram of fuel and

$\leq 1.5 \times 10^{-4} \mathrm{cc} / \mathrm{g}$ hydrogen (from all hydrogenous compounds).

During loading of fuel into the Zircaloy rods, the pellets were exposed to atmospheric conditions and adsorbed a small amount of moisture. Manufacturing controls, based on Equation (3), were placed on the humidity levels and exposure times of the pellets to the air after vacuum-outgassing. Clad tubing and rod internal components were thoroughly cleaned, rinsed and vacuum-dried prior to rod loading to minimize residual volatile gases. Finally, representative fuel rods were sampled for atmospheric purity after corrosion-testing, with the composition of the rod internal atmosphere not being allowed to exceed 2 mole percent total impurities, including total equivalent hydrogen (hydrogen derived from all hydrogenous sources including molecular hydrogen).

Criteria, based on the existence of a threshold level of hydrogen below which local attack does not take place, have been developed to define the conditions of internal hydriding in oxide-fueled rods (References 7, 9 and 10). An analysis of hydride failures in operating reactors correlated various 
parameters to a failure limit and concluded that the "initial-moisture equivalent concentration" in the accessible hot void best fitted the experimental data. This assessment is related to the dependence of hydride formation on the hydrogen flux into the Zircaloy. The flux is a function of the local partial pressure of $\mathrm{H}_{2}$ and thus of the gas phase hydrogen or moisture concentration. This approach showed that failure was not observed at $\mathrm{mg} \mathrm{H}_{2} \mathrm{O} / \mathrm{cm}^{3}$ hot void ratios of less than 2.5 to 3 , as iliustrated in Figure 6 , and that these ratios correlated the available data exceedingly well (References 7 and 10).

The data are primarily from the Halden and other boiling water reactors but the failure/nonfailure boundary limit is applicable over a wide range of irradiation conditions and rod design parameters (References 7 and 10). The equivalent moisture concentration ratios applicable to LWBR fuel rods, tabulated in Table 18, are $\leq 0.13 \mathrm{mg} / \mathrm{cm}^{3}$. The ratios are calculated in two ways. Total hydrogen based on pellet residual gas limits was taken to be equal to the remnant hydrogen $\left(1.5 \times 10^{-4} \mathrm{cc} / \mathrm{g}\right)$ plus hydrogen due to desprbed moisture, including desorbed moisture from internal metal surfaces. The metal surfaces were assumed to have a surface moisture concentration 25 percent of that of pellet surfaces as inferred from the data of Table 15. A total hydrogen calculation was also based on the internal atmosphere hydrogen limit. This limit was taken to be equal to 2 percent of the total gas volume in the fuel rod, multiplied by a factor of 1.25 to account for hydrogen entering the clad during corrosion-testing, plus the remnant hydrogen $\left(1.5 \times 10^{-4} \mathrm{cc} / \mathrm{g}\right)$. The second method resulted in higher calculated equivalent moisture concentrations.

The highest equivalent moisture concentration for an LWBR rod, $0.13 \mathrm{mg} / \mathrm{cm}^{3}$, is superimposed on Figure 6 and shows that the maximum moisture concentration anticipated in LWBR fuel rods is well below, the empirical failure boundary limit. Moreover, it has been observed that, although not all rods with higher ratios always fail, all fuel rods with lower ratios were found never to fail (Reference 7 ).

\section{CONCLUSIONS}

The following conclusions can be drawn relative to the permeability of the internal cladding surfaces in thoria-fueled Zircaloy rods to hydrogen outgassed from the fuel pellets and internal metal components:

1. The internal surface film formed by chemical etching of the Zircaloy cladding is more impermeable to hydrogen than the machined and abraded areas. However, even the pickled film absorbed some hydrogen. 
2. Unless severely scratched, the pickled Zircaloy surfaces absorbed the hydrogen uniformly and thus restricted any possible excessive localized hydriding.

3. No localized hydrogen attack could be detected in scratches produced by the thorium oxide fuel rubbing against the zircaloy cladding during assembly.

4. Both high density thoria fuel and internal metal cladding components adsorb and retain moisture. Vacuum outgassing, storing in a dry atmosphere and minimizing exposure to air during rod loading are needed to control fuel rod moisture levels.

\section{ACKNOWLEDGMENTS}

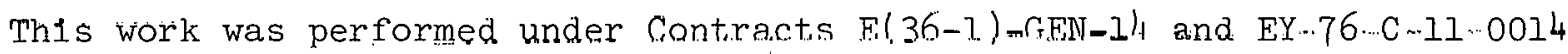
of the U. S. Department of Energy. The author is grateful to the U. S. Department of Energy and the Westinghnuse Electric Corporation for pormission to publish this report.

Many persuns at the Bettis Laboratory have contributed to the work on which this report is based. The author particularly appreriates the assistance and guidance of $\mathrm{J}$. Belle throughout the course of this investigation and for his critical review of the manuscript. R. M. Berman performed the water vapor oxidation and gas chromatrography measurements and the computer programming of the water adsorption data. The mass spectrometric analyses were carried out under the direction of H. D. Cook and J. W. Klinehamer, C. S. Galt.7. ca.lni.aterd the expected fuel rod hydrogen contents. R. L. Fischer helped with the rod corrosion studies. J. E. Rulli, P. A. Antonell.A, G. A. Cicconi and H. E. Himcs assisted in carrying out the gas extraction and hydriding tests. 
REFERENCES

1. D. H. Locke, "Review of Experience with Water Reactor Fuels 1968-1973," Nucl. Eng. Des., 33, 94-124 (1975).

2. D. H. Locke, "Defected Zircaloy Fuel,". Nucl. Eng. Int., 14, 648-52 (1969).

3. D. H. Locke, "The Behavior of Defective Reactor Fuel," Nucl. Eng. Des., 21, 319-30 (1972).

4. J. A. L. Robertson, "Nuclear Fuel Failures, Their Causes and Remedies," INIS-mf-3193, 2, 16-29 (1976).

4a. D. R. Connors, et al, "Design of the Shippingport Light Water Breeder Reactor," WAPD-TM-1208, J anuary 1979.

5. R. J. Smid, "Gas Release from Thoria-Base Oxide Fuel Pellets," WAPD-TM-850 (April 1971).

6. K. Videm, "Properties of Zirconium Base Cladding Materials - Corrosion and Hydrogen Pickup," Nucl. Eng. Des., 21 , 200-11 (1972).

7. R. A. Proebstle, J. H. Davies, T. C. Rowland, D. R. Rutkin, and J. S. Armijo, "The Mechanism of Defection of Zircaloy-Clad Fuel Rods by Internal Hydriding," INIS-mf-3193, 2, 29-48 (1976).

8. H. H. Klepfer, R. B. Richards and T. Trocki, "Fuel Performance in Boiling Water Reactors," Proc. Amer. Power Conf., 34, 169-75 (1972).

9. D. O. Pickman, "Internal Cladding Corrosion Effects," Nucl. Eng. Des., 33, $141-54$ (1975).

10. K. Joon, "Primary Hydride Failure of Zircaloy-Clad Fuel Rods," Trans. Amer. Nucl. Soc., 15, 186-7 (1972).

11. M. F. Lyons, R. F. Boyle, J. H. Davies, V. E. Hazel, and T. C. Rowland, "UO 2 Properties Affecting Performance," Nucl. Eng. Des., 21, 167-99 (1972).

12. A. S. Bain, "Mechanism Causing Hydride Defects at End-Cap Welds of Zircaloy-Sheathed UO," Trans. Amer. Nucl. Soc., 12, 99-100' (1969).

13. F. W. Kramer, "PWR Fuel Performance - The Westinghouse View," INIS-mf$3193,1,50-65(1976)$.

1.4. H. E. Williamson and R. A. Proebstle; "Results with BWR Fuel Improvements," INIS-mf-3193, I, 38-48 (1976).

15. D. W. Shannon, "Role of the Oxidation Rate on the Hydriding of Zirconium Alloys in Gas Atmospheres Containing Hydrogen," HW-766562 REV (February 1963). 
16. R. E. Westerman, "High Temperature Oxidation of Zirconium and Zircaloy-2 in Oxygen and Water Vapor," HW-73511 (April 1962).

17. R. F. Boyle and T. J. Kisiel, "Hydrogen Permeation of Zircaloy-2 Corrosion Films," Bettis Technical Review, WAPD-BT-10, 31-48 (1958).

18. D. L. Douglass, "The Metallurgy of Zirconium," International Atomic Energy Agency, Vienna (1971).

19. R. P. Marshall, "Absorption of Gaseous Hydrogen by Zircaloy-2," J. Less-Common Metals, 13, 45-62 (1967).

20. E. A. Gulbransen and K. F. Andrew, "Mechanism of the Reactor of Hydrogen with Zirconium. Role of Oxide Films, Pretreatments, and Occluded Gases," J. Electrochem. Soc.; 101, 348-53 (1954).

21. E. A. Gulbransen and K. F. Andrew, "Reaction of Hydrogen with Preoxidized Zircaloy-" at 300 to $400^{\circ} \mathrm{C}$," J. Electrochern. Sor., 1.04, 70?-1.? (1957).

22. E. A. Gulbransen and K. F. Andrew, "Nature and Properties of the Thin Oxide Film Formed on Zirconium and Zircaloy," "Reactive Metals," W. K. C'Luugh, Ed., Metallurgical Soc, Cont', '2, 465-76", Interscience, New York (1959).

23. S. Aronson, "Some Experiments on the Permeation of Hydrogen through Oxide Films on Zirconium," Bettis Technical Review, WAPD-BT-19, 75-81 (1960).

24. W. R. Kerr, "Screening Tests of Hydrogen Diffusion Barriers for Zirconium," AI-CE-27 (August 1967).

25. W. Debray, L. Blieding and U. Rosler, "Influence of Initial OxideLayer Formation on the Hydrogen Pickup of Zircaloy," Electrochem. Technol., 4, 113-117 (1966).

26. L. Lunde, "Localized or Uniform Hydriding of Zircaloy: Some Observations on the Effect of Surface Conditions," J. Nucl. Mater., 44, 241-45 (1972).

27. P. J. Shirvington, D. II. Bradhursl, and P. M. Hever, "Accelerated Oxidation of Zirconium Alloys - Significance of Surface Preparation," J. Nucl. Mater.: 44, 79-82 (1972).

28. D. C. Martin, "Arc Welding of Zirconium," pp. 307-20 in "Metallurgy of Zirconium" by B. Lustman and F. Kerze, Jr., McGraw-Hill (1953).

29. A. Garlick, "Accelerated Oxidation Near Zircaloy Welds," J. Nucl. Mater., 1, 332-34 (1972/73).

30. Kirk-Othmer, "Encyclopedia of Chemical Technology," Vol. 7, p. 382-3. 
31. G. Ostberg, "Determination of Hydride Solubility in Alpha Zirconium, Zircaloy-2 and Zircaloy-4," J. Nucl. Mater., 5, 208-15 (1962).

32. J. B. Cordiner and O. C. Dean, "A Study of Gas-Evolution from Sol-Gel Thoria and Thoria-Urania," ORNL-TM-2268 (July 1968).

33. A. S. Denovan, R. W. Ashley, and T. H. Longhurst, "Internal Sources of Hydrogen in Unirradiated $\mathrm{UO}_{2}$ Fuel Elements," AECL-4063 (October. 1971).

34. R. B. Gammage, W. S. Brey, Jr., and B. H. Davis, "Adsorption of Water Vapor by Thorium Oxide and the Effects of Water on the Oxide," J. Colloid Interface Sci., 32, 256-69 (1970).

35. H. F. Holmes and C. H. Secoy, "Heats of Immersion in the Thorium OxideWater system," J. Phys. Chem., 69, 151-8 (1965).

36. H. F. Holmes, E. I. Fuller, Jr., and C. H. Secoy, "Heats of Immersion in the Thorium Oxide-Water System. II. Net Differential Heats of Adsorption," J. Phys. Chem., 70, 436-44 (1966).

37. E. L. Fuller, Jr., H. F. Holmes, C. H. Secoy, and J. E. Stuckey, "Heats of Immersion in the Thorium Oxide-Water System. III. Variation with Specific Surface Area and Outgassing Temperature," J. Phys. Chem., 72, 573-77 (1968).

38. H. F. Holmes, E. L. Fuller, Jr., and C. H. Secoy, "Gravimetric Adsorption Studies on Thorium Oxide. III. Adsorption of Water on Porous and Non-porous Samples," J. Phys. Chem., 72, 2293-2300 (1968).

39. R. B. Gammage and W. S. Brey, Jr., "Stepwise Uptake of Water Vapor by Ground Thorium Oxide," J. Appl. Chem. Biotechnol., 22, 31-7 (1972).

40. E. L. Fuller, Jr., H. F. Holmes, and C. H. Secoy, "Gravimetric Adsorption Studies of Thorium Oxide. II. Water Adsorption at $25.00^{\circ}$," J. Phys. Chem., 70, 1633-6 (1966).

41. J. C. Clayton, "Thnrium Oxide Powder Properties Which are Important to $\mathrm{ThO}_{2}$ and $\mathrm{ThO}_{2}-\mathrm{UO}_{2}$ Fuel Pellet Fabrication," WAPD-TM-1230 (January 1976).

42. C. L. Martell, "Adsorption," McGraw-Hill, New York (1951).

43. T. E. Fischer, "A New Look at Catalysis," Physics Today, 27, 23-8 (May 1974).

44. W. B. Blumenthal, "The Chemical Behavior of Zirconium," D. VanNostrand, New York (1958). 
TABLE 1. CHEMICAL ANALYSIS OF ZIRCALOY-4 COUPONS

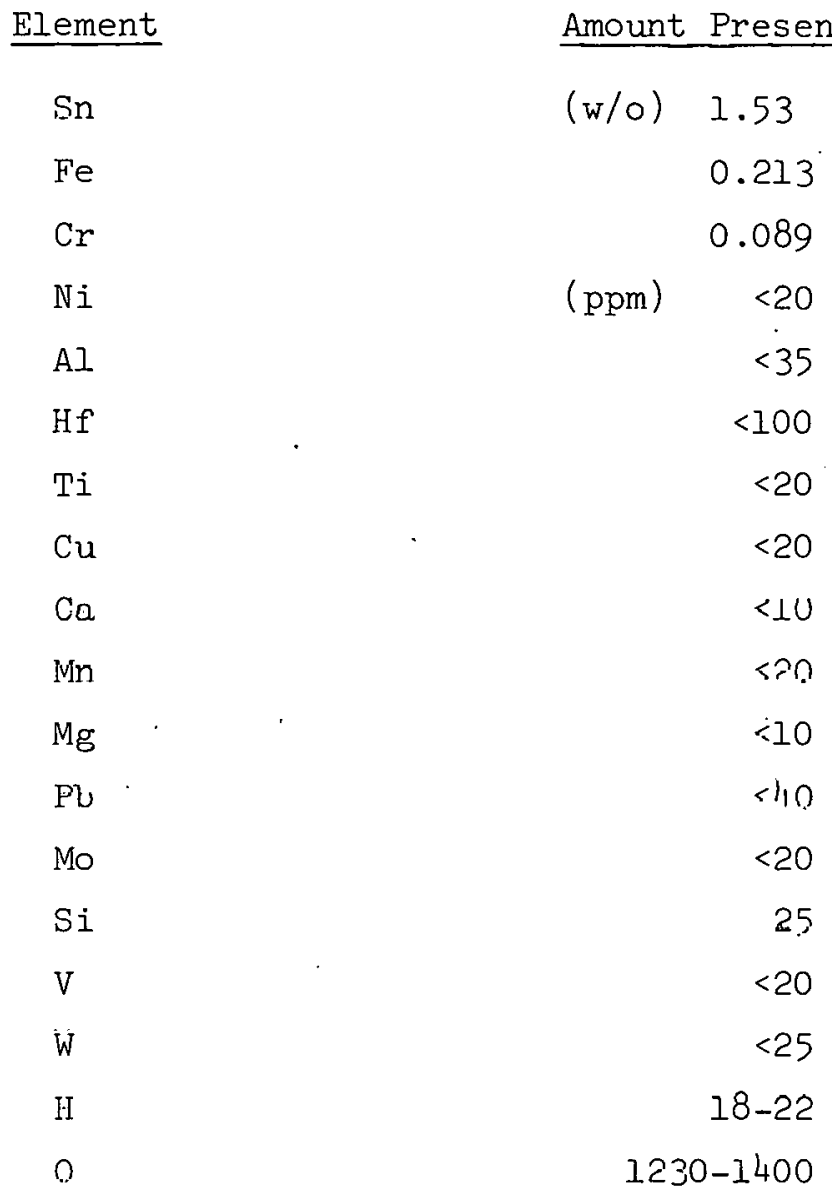

TABLE 2. ZIRCALOY -4 TUBING PROPERTIES

\begin{tabular}{|c|c|c|}
\hline Type & Seed & $\begin{array}{c}\text { Fower r'lattening } \\
\text { Blanket }\end{array}$ \\
\hline Oulside Diameter (in.) & 0.307 & 0.529 \\
\hline Wall Thickness (in.) & 0.026 & 0.029 \\
\hline \% Cnld Wnrk. & $\begin{array}{l}4.5 \text { and Rerystaldized- } \\
\text { Annealed }\end{array}$ & $\begin{array}{l}10 \text { and } 3 \text { tress- } \\
\text { Relief Annealed }\end{array}$ \\
\hline $\begin{array}{l}\text { Vacuum Annealing } \\
\text { Temperature }\left({ }^{\circ} \mathrm{C}\right) \\
\text { Time (hrs) }\end{array}$ & $\begin{array}{l}675 \\
4-8\end{array}$ & $\begin{array}{r}510 \\
4\end{array}$ \\
\hline Surface Condition & Pickled & Pickled \\
\hline Hydrogen (ppm) & $13-17$ & $13-20$ \\
\hline Oxygen (ppm) & $1080-1190$ & $1020-1145$ \\
\hline Grain Size (ASTM \#) & $6-7$ & $7-8$ \\
\hline
\end{tabular}


TABLE 3. HYDROGEN-REACTEL . ZIRCALOY-4 COUPONS

\section{Surface. Treatment}

Abraded; vacuum-annealed 2 hrs at $600^{\circ} \mathrm{C}$ Chemically-etched

Abraded; vacuum-annealed 2 hrs at $600^{\circ} \mathrm{C}$

Abracied; vacuum-annealed 2 hrs at $600^{\circ} \mathrm{C}$

Chemically-etched

Chemically-etched; annealed in helium for 3.5 days at $343^{\circ} \mathrm{C}$

Abraded; vacuum-annealed $2 \mathrm{hrs}$ at $600^{\circ} \mathrm{C}$

Chemically-etched

Chemically-etched; annealed in helium for 3.5 days at $343^{\circ} \mathrm{C}$

Chemically-etched; annealed in helium for 3.5 days at $343^{\circ} \mathrm{C}$

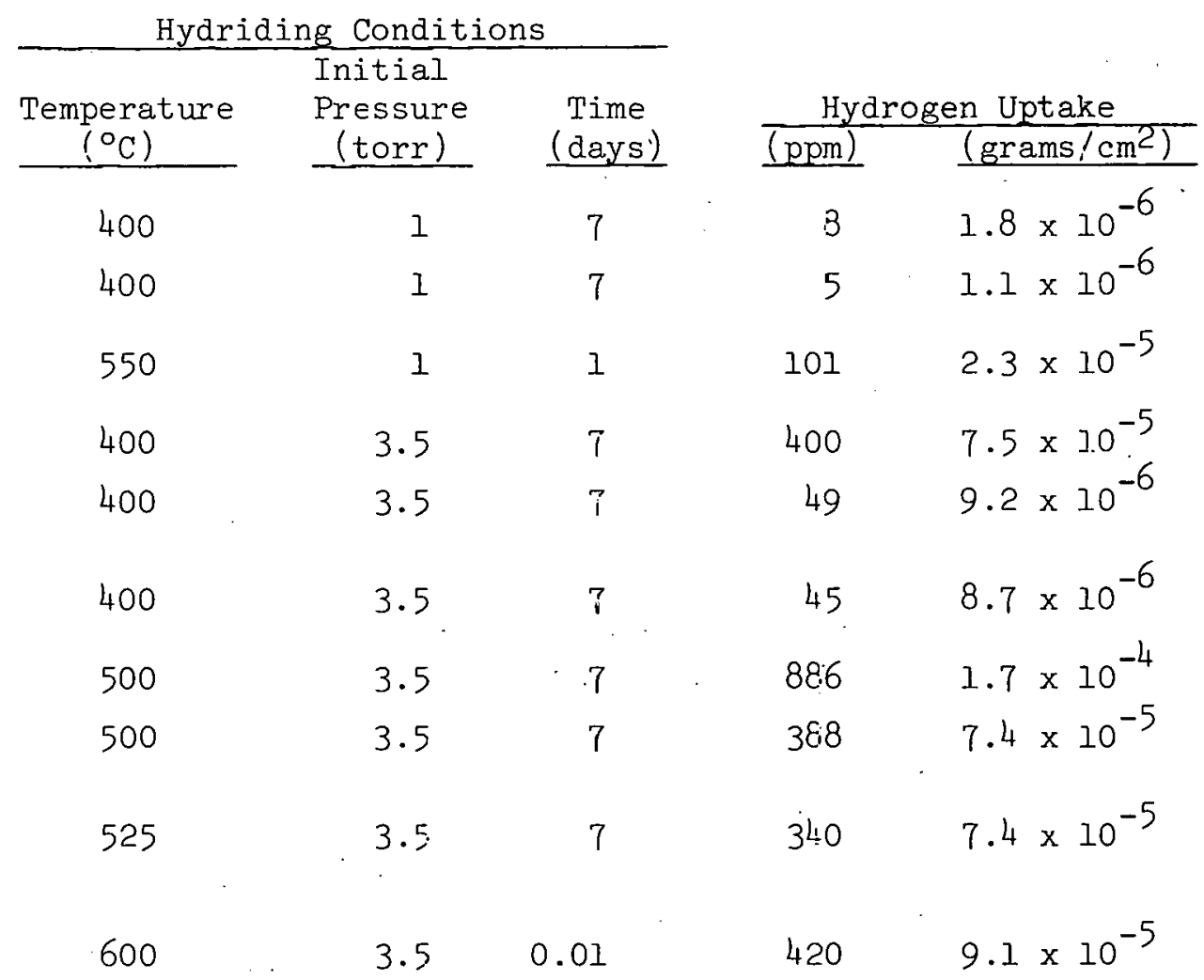


TABLE 4. HฯDROGEN-REACTED* ZIRCALOY -4 COUPONS

\section{Surface Treatment}

Chemically-etcheci

Chemically-etchec

Etched; annealed in helium ior 3.5 cays at $3^{2} 3^{\circ} \mathrm{C}$

Chemically-etched

Chemically-etched; vacuun-annealed for 3 cajs at $360^{\circ} \mathrm{C}$

Weld metal; machined surface with $\approx$ ir filn; vacuum-annealed for 1 day a $300^{\circ} \mathrm{C}$

Weld metal; etcied surface

$* 400^{\circ} \mathrm{C} ; 7$ days
Initial Hy-drogen

Pressure (torr)

1.

3.5

3.5

18.5

18.

18.5

18.5
Hydroger! Uptake

\begin{tabular}{|c|c|}
\hline (prm) & (grams $\left./ \mathrm{cm}^{2}\right)$ \\
\hline 5 & $1.1 \times 10^{-6}$ \\
\hline 49 & $9.2 \times 10^{-6}$ \\
\hline 45 & $8.7 \times 10^{-6}$ \\
\hline 117 & $2.7 \times 1 c^{-5}$ \\
\hline 588 & $1.2 \times 10^{-4}$ \\
\hline 1019 & $1.8 \times 10^{-4}$ \\
\hline 36 & $6.7 \times 10^{-5}$ \\
\hline
\end{tabular}


TABLE 5. HYDROGEN-REACTED SEED RODS

\begin{tabular}{|c|c|c|c|c|c|}
\hline \multirow[b]{3}{*}{ Type } & \multirow[b]{3}{*}{ Surface } & \multicolumn{2}{|c|}{ Hydriding Conditions** } & & \\
\hline & & \multirow{2}{*}{$\begin{array}{l}\text { Temperature } \\
\left({ }^{\circ} \mathrm{C}\right)\end{array}$} & \multirow{2}{*}{$\begin{array}{l}\text { Initial } \\
\text { Pressure } \\
\text { (torr) } \\
\end{array}$} & \multicolumn{2}{|c|}{ Hydrogen Uptake } \\
\hline & & & & $(\mathrm{ppm})$ & (grams $\left./ \mathrm{cm}^{2}\right)$ \\
\hline tubing & machined edge & 500 & 3.5 & 135 & $1.4 x \cdot 10^{-4}$ \\
\hline tubing & pickled and annealed* & 500 & 3.5 & 107 & $5.1 \times 10^{-5}$ \\
\hline end eap & pickled and annealed* & 500 & 3.5 & 46 & $3.8 \times 10^{-5}$ \\
\hline & weld area* & 500 & 3.5 & 62 & $2.4 \times 10^{-5}$ \\
\hline tubing & machined edge & 400 & 3.5 & 126 & $1.9 \times 10^{-4}$ \\
\hline tubing & pickled and annealed* & 400 & 3.5 & 87 & $4.2 \times 10^{-5}$ \\
\hline end cap & pickled and annealed* & 400 & 3.5 & 24 & $2.0 \times 10^{-5}$ \\
\hline tubing & machined edge & 400 & 18.5 & 233 & $4.3 \times 10^{-4}$ \\
\hline tubing. & pickled and annealed* & 400 & 18.5 & 147 & $7: 0 \times 10^{-5}$ \\
\hline end cap & pickled and annealed* & 400 & 18.5 & 67 & $5.6 \times 10^{-5}$ \\
\hline tubing & machined edge & 400 & 36 & 521 & $1.6 \times 10^{-3}$ \\
\hline tubing & pickled and annealed* & 400 & 36 & 208 & $1.0 \times 10^{-4}$ \\
\hline end cap & pickled and annealea* & 400 & 35 & 151 & $1.3 \times 10^{-4}$ \\
\hline
\end{tabular}

* Heated in helium for 3.5 days at $343^{\circ} \mathrm{C}$

**7 days exposure time 
TABLE 6. H־DROGEN-REACTED BLANKET RODS

\begin{tabular}{|c|c|}
\hline Type & Surfac $\equiv$ \\
\hline tubing & machined edge \\
\hline tubing & picklec and annealeć. \\
\hline end cap & pickled and annealeci \\
\hline & weld area* \\
\hline tubing & machined edge \\
\hline tubing & oickled and znnealed* \\
\hline end cap & pickled and annealed* \\
\hline tubing & machined edge \\
\hline tubing & pickled and annealed* \\
\hline end cap & picklec and annealed* \\
\hline tubing & machined edge \\
\hline tubing & pisklec and arnealed* \\
\hline end cap & piokled and ar.nealed* \\
\hline
\end{tabular}

\begin{tabular}{cc}
$\begin{array}{c}\text { Hydriding Conzitions** } \\
\text { Temperature } \\
\left({ }^{\circ} \mathrm{C}\right)\end{array}$ & $\begin{array}{c}\text { Iritial } \\
\text { Pressure } \\
\text { (torr) }\end{array}$ \\
\hline 350 & 3.5 \\
350 & 3.5 \\
$35 C$ & 3.5 \\
$35 C$ & 3.5 \\
$45 C$ & 3.5 \\
$45 C$ & 3.5 \\
$45 C$ & 3.5 \\
$40 C$ & 10.5 \\
400 & 10.5 \\
400 & 10.5 \\
350 & -8.5 \\
350 & $=8.5$ \\
350 & 18.5
\end{tabular}

*Heated in helium for 3.5 deys at $343^{\circ} \mathrm{C}$

**7 days exposure time 
TABLE 7. HYDROGEN-REACTED $\left(400^{\circ} \mathrm{C}\right.$ AND 18.5 TORR) ZIRCALOY-4 CURVED SPECIMENS

Chemically-etched; no scratches

Chemically-etched; two crossed 0.5-inch scratches

Chemically-etched: L-shaped 1.0-inch scratch

Chemically-etched; 0.75 -inch diagoral scratch

Chemically-etched; 0.75-inch diagonal scratch

\section{Reaction \\ Time \\ (hrs) \\ 168}

0.5

$1 \cdot 5$

1

6
Hydrogen Uptake

\begin{tabular}{cc}
\hline (torr) & (ppm) \\
\cline { 2 - 2 } 2.3 & 102 \\
18.5 & $1412^{*}$ \\
$9 * *$ \\
& $5^{* * *}$ \\
& $3579^{*}$ \\
18.5 & $7^{* *}$ \\
& $3^{* * *}$ \\
& $4223^{*}$ \\
18.5 & $14^{* *}$ \\
& $1 * * *$ \\
18.5 & $1511^{*}$ \\
& $129 * *$ \\
& $87^{* * *}$
\end{tabular}

*Grossly-hydrided scratched area

**Clear scratched area (no gross bydriding)

** Scratch-free area 
TABLE 8. HYDROGEN-REACTED* ZIRCALOY -4 CURVED SPECIMENS

Chemically-etched; no scratches

Chemically-etched; 0.75 -inch horizontal scratch

Chemically-etched; two diagonal 1-inch scratches
Hydrogen Uptake

(torr)

1.7

101

3.5

$440 * *$ $160 * * *$

15.0

$843,940 * *$ $349 * * *$

* $400^{\circ} \mathrm{C}, 7$ days, 18.5 torr $\mathrm{H}_{2}$; trace $\mathrm{O}_{2}$

* Scratched areas

***Scratch-free areas

TADLP 9. ZIRCALUY TUBE'S EXYUSE'D TO WATER VAPOR

Sample

Temperature

$\left({ }^{\circ} \mathrm{C}\right)$

$\left(\mathrm{O}_{\mathrm{H}^{\circ}}\right)$

Pressure $\left(\mathrm{H}_{2} \mathrm{O}\right)$, torr

Initial Weight, $g$

Weight Gain, mg
's'c'-L'́M -

343

650

9

7.7699

4.0

Hyörngen Analysee (ppm)
Lind Cap

Wcld Metal

Tubing

Cut End
21

20

27
S2-21M

371.

700

19

7.7325

13.7

20

19

22

30 
TABLE 10. SEED ROD PROCESS CONTROL SAMPLES

\begin{tabular}{|c|c|c|c|c|c|c|c|c|c|c|c|}
\hline \multirow[b]{2}{*}{ Contaminan ${ }^{*}$} & \multirow{2}{*}{$\begin{array}{c}\text { Internal } \\
\text { Pressure } \\
\text { (atmospheres) } \\
\end{array}$} & \multirow[b]{2}{*}{$\mathrm{He}$} & \multirow[b]{2}{*}{$\mathrm{H}_{2}$} & \multirow[b]{2}{*}{$\mathrm{N}_{2} / \mathrm{CO}$} & \multirow{2}{*}{$\underline{0_{2}}$} & \multirow{2}{*}{$\mathrm{CH}_{4}$} & \multirow{2}{*}{$\begin{array}{c}\text { Aliphatic } \\
\text { Hydrozarbons }\end{array}$} & \multirow{2}{*}{$\begin{array}{c}\text { Aromatic } \\
\text { Hycrosarbons }\end{array}$} & \multicolumn{2}{|c|}{$\begin{array}{c}\text { Cladding } \\
\text { Hycrogen } \\
\text { Cortent } \\
\text { (ppm) }\end{array}$} & \multirow[t]{2}{*}{$\begin{array}{c}\text { Oxide } \\
\text { Interference } \\
\text { Color } \\
\end{array}$} \\
\hline & & & & & & & & & $\underline{\underline{\text { End }}}$ & Center & \\
\hline none (control) & 0.96 & 99.58 & $t^{* *}$ & 0.06 & 0.01 & 0.25 & 0.07 & 0.02 & 20 & 20 & Gold-Brown \\
\hline none (control) & 0.93 & 99.34 & $t^{* *}$ & 0.06 & 0.009 & 0.22 & 0.25 & 0.11 & 21 & 20 & Darker Brown \\
\hline $0.3 \mathrm{mg}$ particulate mat:er & 0.93 & 99.12 & 0.005 & 0.07 & 0.01 & 0.50 & 0.16 & 0.11 & 19 & 17 & Darker Brown \\
\hline $0.2 \mathrm{ml}$ vacuum pump oil & 1.17 & 80.8 & 0.13 & $0.97 * * *$ & 0.02 & 2.5 & 15.3 & 0.33 & 22 & 21 & Blue-Brown \\
\hline
\end{tabular}

* Deliberately introduced prior to seal welding.

**t indicates concentration is $<0.005$ mole $T$, but detected.

***Major contributor was $\mathrm{N}_{2}$; only minor quentities of $\mathrm{CO}$ present. 


\begin{tabular}{|c|c|c|c|c|c|c|}
\hline \multirow[b]{2}{*}{$\begin{array}{l}\text { Lot* } \\
\text { No. }\end{array}$} & \multirow[b]{2}{*}{$\begin{array}{l}\text { BET Surface } \\
\text { Area }\left(\mathrm{m}^{2} / \mathrm{g}\right) \\
\end{array}$} & \multirow[b]{2}{*}{$\begin{array}{l}\text { Moisture } \\
(\mathrm{w} / 0)\end{array}$} & \multirow[b]{2}{*}{$\begin{array}{c}\text { Adsorbed } \\
\text { Monolayer* }\end{array}$} & \multicolumn{3}{|c|}{4 Weeks' Exposure to Ambient Air } \\
\hline & & & & $\begin{array}{l}\text { BET Surface } \\
\text { Area }\left(\mathrm{m}^{2} / \mathrm{g}\right) \\
\end{array}$ & $\begin{array}{l}\text { Moisture } \\
(\mathrm{w} / \mathrm{O})\end{array}$ & $\begin{array}{c}\text { Adsorbed } \\
\text { Monolayer** }\end{array}$ \\
\hline 005 & 7.5 .7 & 0.19 & 0.9 & 7.99 & 0.41 & 1.9 \\
\hline 015 & $7.51,7.70$ & $0.13,0.14$ & 0.6 & 7.76 & 0.31 & 1.4 \\
\hline 025 & $7.45,7.64$ & $0.11,0.12$ & 0.5 & 3.38 & 0.34 & 1.5 \\
\hline 034 & $7.44,7.49$ & $0.15,0.15$ & 0.7 & 3.30 & 0.37 & 1.7 \\
\hline 043 & $6.93,7.04$ & $0.17,0.18$ & 0.9 & 7.59 & 0.38 & 1.8 \\
\hline 054 & $6.36,6.89$ & $0.20,0.28$ & 1.3 & 6.52 & 0.43 & 2.3 \\
\hline
\end{tabular}

*Powder preparation and measurements were made over, an 13 -month Jeriod. Mcisture measured by moisture analyzer $t \geqslant c h r i q u e$.

* Calculated on the basis that a monomoleculer layer of adsorbed water vapor -s equivalent to $2.84 \times 10^{-3} \mathrm{~g} \mathrm{I}_{2} \mathrm{O} / \mathrm{cn}^{2}$; i.e., the mass of 1 water molecule $\left(3 \times 10^{-23} \mathrm{~g}\right)$ dirided by its area $\left(10.6 \mathrm{~A}^{2}\right)$. 
TABLE 12. METHODS OF ACHIEVING HUMIDITY CONDITIONS FOR THORIA PELLET MOISTURE ADSORPTION EXPERIMENTS

\section{Atmosphere*}

Vacuum Desiccator ( 20 torr) containing $\mathrm{Mg}\left(\mathrm{ClO}_{4}\right)_{2}$

Vacuum Desiccator ( 20 torr)

Ambient Laboratory Air

Closed Cabinet Containing Excess Saturated Aqueous $\mathrm{NH}_{4} \mathrm{Cl}-\mathrm{KNO}_{3}$

Solution

Closed Cabinet Containing Excess Saturated Aqueous $\mathrm{NH}_{4} \mathrm{CL}$ Solution

Closed Cabinet Containing Excess Saturated Aqueous $\mathrm{NH}_{4} \mathrm{H}_{2} \mathrm{PO}_{1}$

Solution

*25 to $30^{\circ} \mathrm{C}$
Measured Relative Humidity

$(\%)$

10

40

20-45

72

79

93 
TABLE 13. MOISTJRE CONTENT OF ThO 2 REFLECTCF PELLETS

(Vacuum Extraction - Mass Spectrcmetry)

Relative
Humidity

$(\%)$

93

93

93

$30-45$

25

20-30

30

$40 *$

72

93

93

$<10^{*}$

*Partial vacuum
Annealing Temperature $\left({ }^{\circ} \mathrm{C}\right)$

700

700

700

700

700

$70 \mathrm{C}$

700

700

700

350

350

350
Water Vapor Evolved (cc/g) (STP) $1.4 \times 10^{-4}$ $1.3 \times 10^{-4}$

$8.7 \times 10^{-5}$ $7.5 \times 10^{-5}$ $2.0 \times 10^{-5}$ $5.3 \times 10^{-5}$ $5.7 \times 10^{-7}$ $1.2 \times 10^{-5}$ $5.6 \times 10^{-5}$ $6.1 \times 10^{-5}$ $5.1 \times 10^{-5}$ $3.1 \times 10^{-5}$ 
TABLE 14. LOW-TEMPERATURE EXTRACTIONS: REFLECTOR ThO 2 PRODUCTICN PELLETS

\begin{tabular}{|c|c|c|c|c|c|c|c|c|c|c|}
\hline \multirow{2}{*}{$\begin{array}{l}\text { PEllet Exposure } \\
\text { Conditions }\end{array}$} & \multirow{2}{*}{$\begin{array}{l}\text { Extraction } \\
\text { Temperature } \\
\left({ }^{\circ} \mathrm{C}\right) \\
\end{array}$} & \multicolumn{3}{|c|}{ Gas Release (cc/g STP) } & \multicolumn{6}{|c|}{ Gas Somposition $(\%)$} \\
\hline & & Total & Hydrogen & Water & $\mathrm{H}_{2}$ & $\mathrm{H}_{2} \mathrm{O}$ & $\mathrm{CO}^{3}$ & $\mathrm{CO}$ & $\mathrm{CH}_{4}$ & Organics \\
\hline \multirow[t]{2}{*}{$\begin{array}{l}\text { As-sintered; moderate } \\
\text { humidity exposure }(\sim 55 \%)\end{array}$} & $\begin{array}{l}350 \\
700\end{array}$ & $\begin{array}{r}1.4 \times 10^{-4} \\
9.0 \times 10^{-4} \\
\end{array}$ & $\begin{array}{r}1.0 \times 10^{-5} \\
37.5 \times 10^{-5} \\
\end{array}$ & $\begin{array}{l}3.9 \times 10^{-5} \\
0.1 \times 10^{-5} \\
\end{array}$ & $\begin{array}{r}7.3 \\
41.6 \\
\end{array}$ & $\begin{array}{r}27.5 \\
1.2 \\
\end{array}$ & $\begin{array}{l}37.0 \\
32.2 \\
\end{array}$ & $\begin{array}{l}12.8 \\
\underline{18.3} \\
\end{array}$ & $\begin{array}{l}1.3 \\
2.4 \\
\end{array}$ & $\begin{array}{r}14.1 \\
4.3 \\
\end{array}$ \\
\hline & Total & $1 C .4 \times 10^{-4}$ & $38.5 \times 10^{-5}$ & $4.0 \times 10^{-5}$ & 37.0 & 3.8 & $32 . .8$ & 17.6 & 2.3 & 6.5 \\
\hline $\begin{array}{l}\text { Vaccum-degassed; * high } \\
\text { humidity exposure ( } 65 \text { to } 90 \% \text { \% }\end{array}$ & 800 & $5.4 \times 10^{-4}$ & $9.7 \times 10^{-5}$ & $=.6 \times 10^{-4}$ & 18.0 & 30.1 & 13.0 & 11.6 & 4.4 & 22.9 \\
\hline \multirow[t]{2}{*}{$\begin{array}{l}\text { Vacuum-degassed; } * \text { high } \\
\text { humidity exposure ( } 55 \text { to } 80 \% \text { ) }\end{array}$} & $\begin{array}{l}300 \\
450 \\
800\end{array}$ & $\begin{array}{r}1.4 \times 10^{-4} \\
0.8 \times 10^{-4} \\
5.5 \times 10^{-4} \\
\end{array}$ & $\begin{array}{r}0.2 \times 10^{-5} \\
2.0 \times 10^{-5} \\
22.2 \times 10^{-5} \\
\end{array}$ & $\begin{array}{l}9.0 \times 10^{-5} \\
0.2 \times 10^{-5} \\
0.3 \times 10^{-5} \\
\end{array}$ & $\begin{array}{r}1.1 \\
25.3 \\
63.3 \\
\end{array}$ & $\begin{array}{r}64.0 \\
1.9 \\
1.0 \\
\end{array}$ & $\begin{array}{r}19.3 \\
22.2 \\
7.2 \\
\end{array}$ & $\begin{array}{r}6.9 \\
7.5 \\
25.4 \\
\end{array}$ & $\begin{array}{r}1.4 \\
13.8 \\
--- \\
\end{array}$ & $\begin{array}{r}7.5 \\
23.2 \\
3.1 \\
\end{array}$ \\
\hline & Total & $5.7 \times 10^{-4}$ & $24.4 \times 10^{-5}$ & $9.5 \times 10^{-5}$ & 42.8 & 16.7 & $1 \equiv .1$ & 18.4 & 2.2 & 6.7 \\
\hline \multirow{2}{*}{ 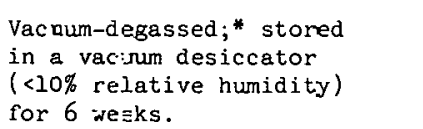 } & $\begin{array}{l}350 \\
700\end{array}$ & $\begin{array}{r}1.9 \times 10^{-4} \\
1.4 \times 10^{-4} \\
\end{array}$ & $\begin{array}{l}0 . \dot{\vec{z}} \times 10^{-5} \\
2 . \dot{z} \times 10^{-5} \\
\end{array}$ & $\frac{3.5 \times 10^{-5}}{---}$ & $\begin{array}{r}2.4 \\
65.4 \\
\end{array}$ & $\begin{array}{l}38.5 \\
---\end{array}$ & $\begin{array}{r}25.8 \\
\varepsilon .4 \\
\end{array}$ & $\begin{array}{l}11.7 \\
18.2 \\
12\end{array}$ & $\begin{array}{l}5.0 \\
4.4 \\
\end{array}$ & $\begin{array}{r}16.6 \\
3.6 \\
\end{array}$ \\
\hline & Total & $2.3 \times 10^{-4}$ & $9.4 \times 10^{-5}$ & $3.5 \times 10^{-5}$ & 110.9 & 15.2 & $1 \div .2$ & $15: 5$ & 4.6 & 8.5 \\
\hline
\end{tabular}

*2 jours at $1000^{\circ} \mathrm{C}$ 
TABLE 15. LLW TEMPIRATURE EXTRACAIJN: REFLECTCR INCONEI ALLCY X-750 PLENUM SPRINGS

\begin{tabular}{|c|c|c|c|c|c|c|c|c|c|}
\hline \multirow[b]{2}{*}{ Spring Condition } & \multirow{2}{*}{$\begin{array}{l}\text { Extraction } \\
\text { Terperature } \\
\quad\left({ }^{\circ} \mathrm{C}\right) \\
\end{array}$} & \multirow[b]{2}{*}{$\frac{\text { Total }}{\mathrm{SCC}}$} & \multirow[b]{2}{*}{$\frac{\text { Gas Release }}{\text { (ca/g STP) }}$} & \multicolumn{6}{|c|}{ Gas Composition (\%) } \\
\hline & & & & $\mathrm{H}_{\varepsilon}$ & $\mathrm{H}_{2}$ & $\mathrm{CO}_{2}$ & $\mathrm{CO}$ & $\mathrm{CH}_{4}$ & Organics \\
\hline Cleaned and & 350 & 0.137 & $2.3 \times 10^{-3}$ & 17.2 & 68.5 & 5.8 & 6.7 & 0.2 & 1.6 \\
\hline nitrogen-dried & 700 & 0.171 & $2.9 \times 10^{-3}$ & 84.8 & 0.2 & 2.5 & 10.6 & 0.7 & 1.2 \\
\hline Cleaned; vacuum-dried & 350 & 0.144 & $2.4 \times 10^{-3}$ & 23.8 & $56 . .8$ & 7.7 & 6.3 & 2.4 & 3.0 \\
\hline $\begin{array}{l}\left.\text { (I hour, } 110^{\circ} \mathrm{C}\right) \\
\text { stored } 16 \text { hours }\end{array}$ & 700 & 0.166 & $2.9 \times 10^{-3}$ & 81.7 & 0.1 & 2.3 & 13.8 & 0.7 & 1.4 \\
\hline $\begin{array}{l}\text { Cleaned; vaclum-dried } \\
\text { ( I hour, } 110^{\circ} \mathrm{C} \text { ); } \\
\text { stored } 32 \text { hours }\end{array}$ & $\begin{array}{l}350 \\
700\end{array}$ & $\begin{array}{l}0.210 \\
0.164\end{array}$ & $\begin{array}{l}=.5 \times 10^{-3} \\
c .5 \times 10^{-3}\end{array}$ & $\begin{array}{r}2.9 \\
80.1\end{array}$ & $\begin{array}{r}71: ? \\
C .4\end{array}$ & $\begin{array}{l}9.1 \\
2.5\end{array}$ & $\begin{array}{l}13.8 \\
15.4\end{array}$ & $\begin{array}{l}0.5 \\
0.7\end{array}$ & $\begin{array}{l}2.6 \\
0.8\end{array}$ \\
\hline
\end{tabular}


TABLE 16. MASS SPECTROMETRIC ANALYSES OF PREPRODUCTION FUEL ROD INTERNAL ATMOSFHERE

\begin{tabular}{|c|c|c|c|c|c|c|c|c|c|}
\hline \multirow[b]{2}{*}{$\begin{array}{l}\text { Rod } \\
\text { Type }\end{array}$} & \multicolumn{2}{|c|}{ Fuel Pellet Properties } & \multirow[b]{2}{*}{$\begin{array}{l}\text { Corrosion- } \\
\text { Tested } \\
\end{array}$} & \multicolumn{6}{|c|}{ Int $=$ rnal f.tmosphere $(\%)$} \\
\hline & Composition & $\begin{array}{c}\text { Vacunm-Degassing } \\
\text { Conditions } \\
\end{array}$ & & $\mathrm{He}$ & $\mathrm{H}_{\mathrm{P}}$ & $\mathrm{N}_{2}$ &. $\mathrm{O}_{2}$ & $\mathrm{CO}$ & Organics \\
\hline Reflector & Thoria & 2 hoars at $1000^{\circ} \mathrm{C}$ & NO & 100.00 & -- & -- & -- & -- & -- \\
\hline Reflector & Thoria & 2 howrs at $1000^{\circ} \mathrm{C}$ & No & 99.99 & $t$ & $<0.005$ & $<0.005$ & -- & $<0.01$ \\
\hline Reflector & Thoria & 2 hours at $1000^{\circ} \mathrm{C}$ & No & 99.84 & -- & 0.14 & 0.02 & -- & -- \\
\hline Reflector & Thoria & 2 hours at $1000^{\circ} \mathrm{C}$ & YES* & 99.70 & $<0.005$ & 0.04 & $\mathbf{t}$ & -- & 0.26 \\
\hline Reflector & Thoria & 2 hours at $1000^{\circ} \mathrm{C}$ & YES* & 99.30 & 0.11 & 0.03 & 0.02 & 0.11 & 0.43 \\
\hline Reflector & Thoria & 2 hodrs at $1000^{\circ} \mathrm{C}$ & YES* & 99.14 & 0.16 & 0.10 & 0.01 & 0.10 & 0.44 \\
\hline Reflector & $\begin{array}{l}\text { Stainless } \\
\text { Steel }\end{array}$ & 5 hours at $510^{\circ} \mathrm{C}$ & Nó & 100.00 & -- & -- & -- & -- & -- \\
\hline Reflector & $\begin{array}{l}\text { Stainless } \\
\text { Steel }\end{array}$ & 5 hours at $510^{\circ} \mathrm{C}$ & YES* & 99.88 & 0.004 & 0.009 & -- & -- & 0.106 \\
\hline Blanket & $\begin{array}{l}\text { Thoria- } \\
\text { Urania }\end{array}$ & 2 hours at $1000^{\circ} \mathrm{C}$ & YES* & 99.96 & $t$ & $t$ & $\mathrm{t}$. & -- & 0.04 \\
\hline Blanket & $\begin{array}{l}\text { Thoria- } \\
\text { Urania }\end{array}$ & 2 hours at $1000^{\circ} \mathrm{C}$ & YES* & $99.55^{\circ}$ & 0.02 & 0.14 & 0.02 & -- & 0.27 \\
\hline Blanket & $\begin{array}{l}\text { Thoria- } \\
\text { Urania }\end{array}$ & 4 hcurs at $800^{\circ} \mathrm{C}$ & YES* & 98.28 & 0.02 & 0.17 & 0.03 & -- & 1.50 \\
\hline Seed & Thoria & 4 hcurs at $850^{\circ} \mathrm{C}$ & No & 99.99 & -- & 0.01 & -- & -- & -- \\
\hline Seed & Thoria & 4 hcurs at $850^{\circ} \mathrm{C}$ & YES** & 99.71 & 0.13 & 0.02 & -- & 0.08 & 0.06 \\
\hline Seed & Copper & 4 hcurs at $400^{\circ} \mathrm{C}$ & No & 99.98 & -- & 0.01 & -- & 0.01 & -- \\
\hline Seed & Copper & 4 heurs at $400^{\circ} \mathrm{C}$ & YES** & 99.77 & 0.17 & 0.02 & -- & 0,06 & 0.03 \\
\hline $\begin{array}{l}* 3.5 \text { days } \\
* * 14 \text { days }\end{array}$ & $\begin{array}{l}43^{\circ} \mathrm{C} \\
0^{\circ} \mathrm{C}\end{array}$ & & & & & & & & \\
\hline
\end{tabular}


TABLE 17. CHEMICAL ANALYSES OF PREPRODUCTION REFLECTOR ZIRCALOY TUBING

Surface Condition

Clear

Black-

Spotted

Frosty

\begin{tabular}{ccc}
\multicolumn{3}{c}{ Amount Present (ppm) } \\
\hline Carbon & Fluorine & $\frac{\text { Hydrogen }}{99}$ \\
90.2 & 9 \\
168 & 0.9 & 11 \\
81 & 2.0 & 8
\end{tabular}


TABLE 18. COMPARISON OF LIMITS ON TOTAL HYDROGEN IN LWBR FUEL RODS WITH HYDRIDE FAILURE BOUNDARY

A. Cn Basis of Pellet Residual Gas Linit

\begin{tabular}{|c|c|c|c|c|c|}
\hline Rod Type & $\begin{array}{c}\text { Total } \\
\text { Equivalent } \\
\text { Hydrogen } \\
\text { at Limit (cc) } \\
\end{array}$ & $\begin{array}{l}\text { Equivalent } \\
\text { Moisture* } \\
\text { Cortent } \\
\left(\mathrm{mg} \mathrm{H}_{2} \mathrm{O}\right) \\
\end{array}$ & $\begin{array}{c}\text { Plenum } \\
\text { Volume (cc) }\end{array}$ & $\begin{array}{l}\text { Equivalent } \\
\text { Moisture } \\
\text { Concentration } \\
\left(\mathrm{mg} \mathrm{H}_{2} \mathrm{O} / \mathrm{cc}\right) \\
\end{array}$ & $\begin{array}{l}\text { Factor of Safety** } \\
\text { Relative to } \\
\text { Failure Boundary }\end{array}$ \\
\hline $\begin{array}{l}\text { Seed } \\
\text { Standard Blarket } \\
\text { Power Flattening Blanket } \\
\text { Reflector }\end{array}$ & $\begin{array}{l}0.260 \\
0.8=0 \\
0.7=3 \\
1.520\end{array}$ & $\begin{array}{l}0.209 \\
0.651 \\
0.573 \\
1.221\end{array}$ & $\begin{array}{l}5.45 \\
14.8 \\
12.7 \\
11.9\end{array}$ & $\begin{array}{l}0.038 \\
0.044 \\
0.045 \\
0.103\end{array}$ & $\begin{array}{l}66 \\
57 \\
56 \\
24\end{array}$ \\
\hline
\end{tabular}

B. On Basis of 2 Percent Equivalent $\mathrm{H}_{2}$ (maximum) in Atmosphere of Corrosion-Tested Rods

$\begin{array}{lllll}\text { Seed } & 0.454 & 0.365 & 5.45 & 0.067 \\ \text { Stancard Blanket } & 1.196 & 0.961 & 14.8 & 0.065 \\ \text { Power Flattening. Blanket } & 1.056 & 0.849 & 12.7 & 37 \\ \text { Reflector } & 1.931 & 1.552 & 11.9 & 37 \\ & & & 0.067 & 0.130\end{array}$

*Equivalent moisture $\left(\mathrm{mg} \mathrm{H}_{2} \mathrm{O}\right)=\operatorname{Total~}_{2}(\mathrm{cc})\left(\frac{18 \mathrm{mg} \mathrm{H_{2 }}}{22.4 \mathrm{cc} \mathrm{H}_{2}}\right)$

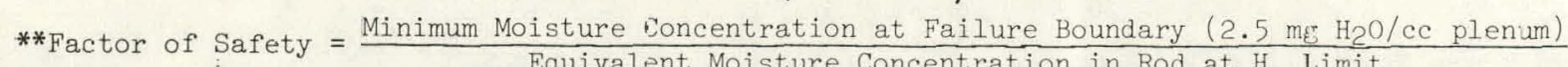




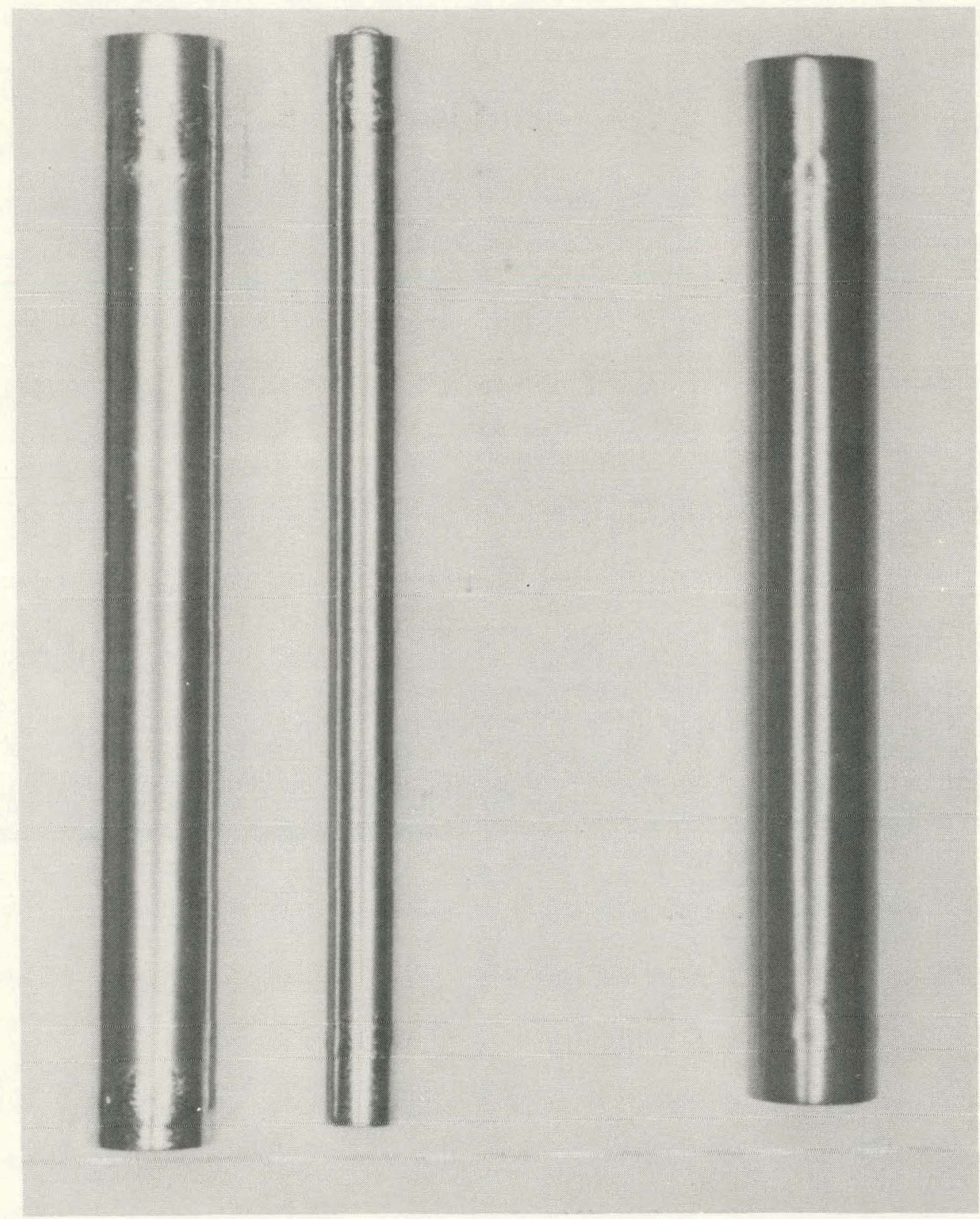

Figure 1. Miniature Seed and Blanket Rods 


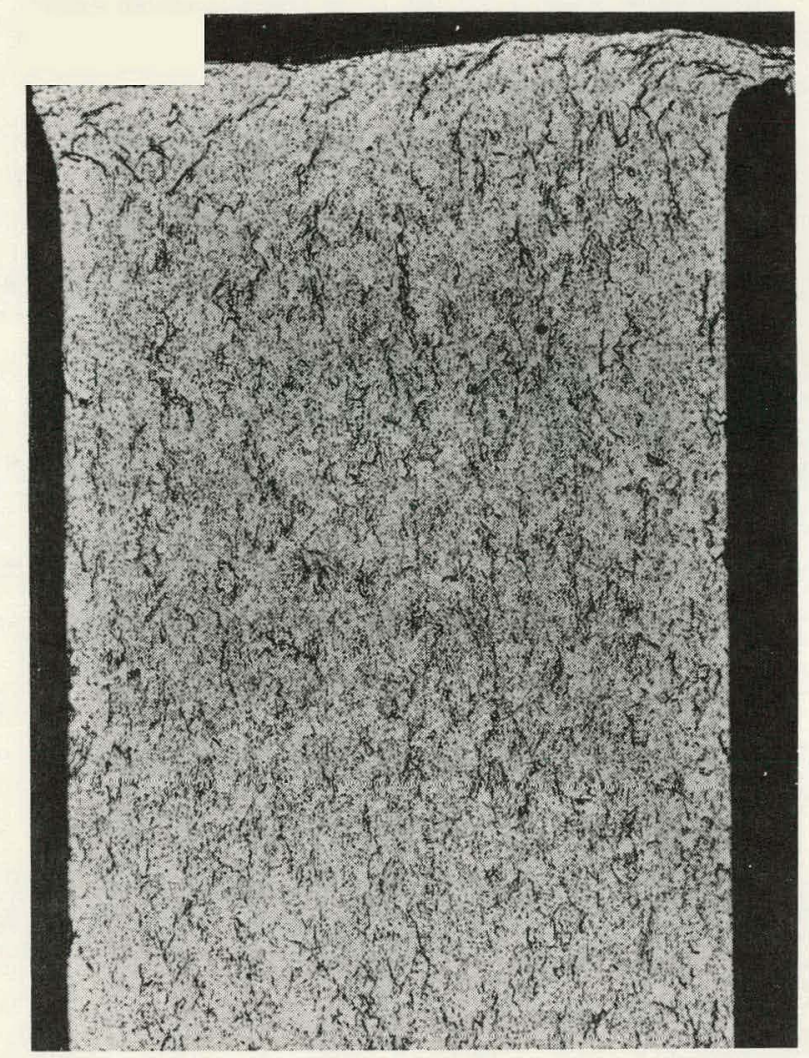

(a) Machined Edge, tubing; $226 \mathrm{ppm}_{2}$

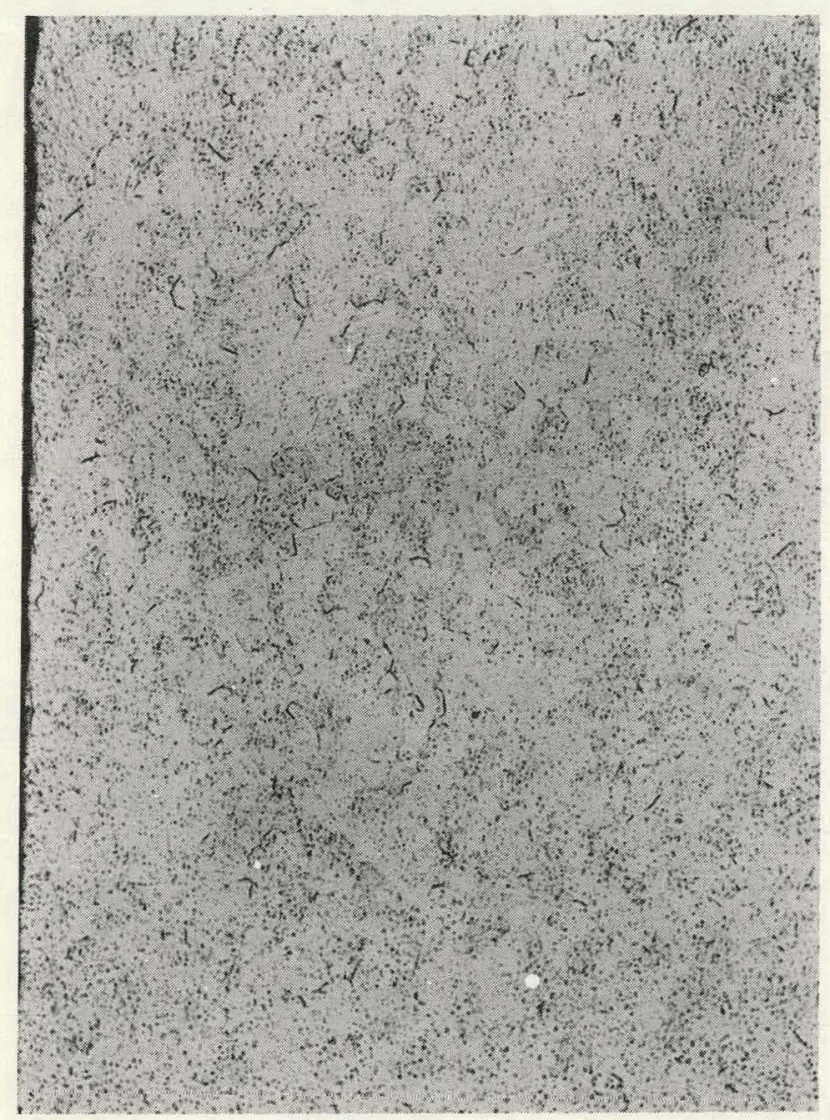

(c) Etched End Cap; 55 ppm $\mathrm{H}_{2}$

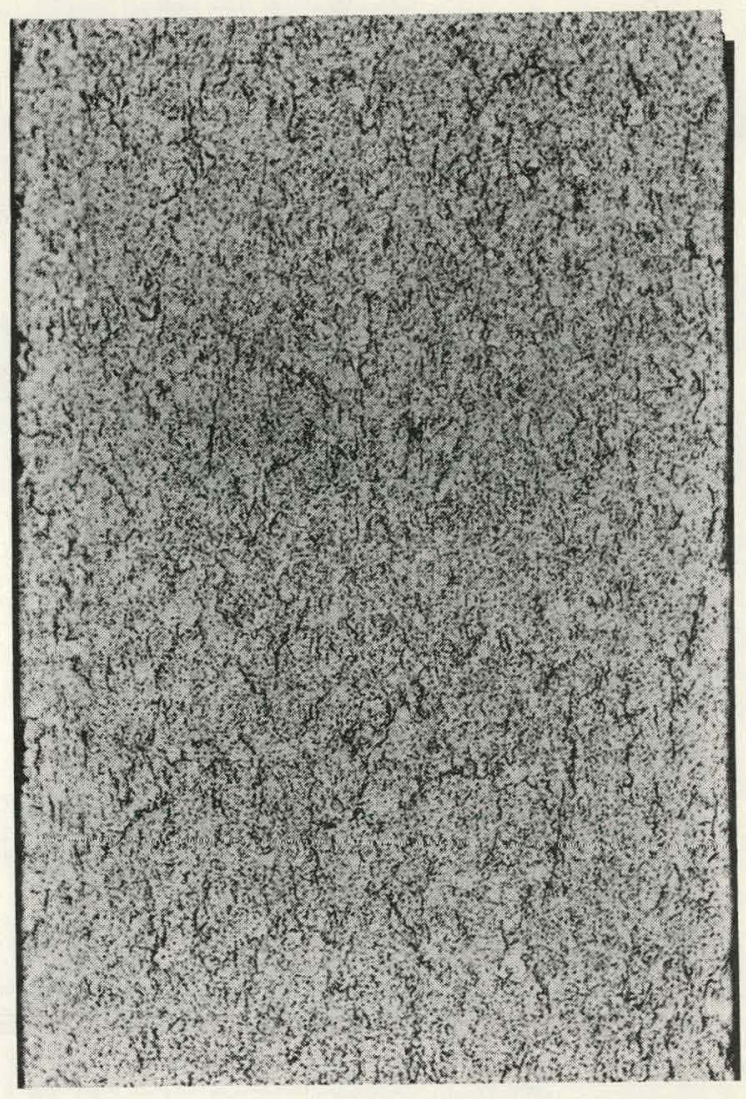

(b) Etched Tubing; 125 ppm $\mathrm{H}_{2}$

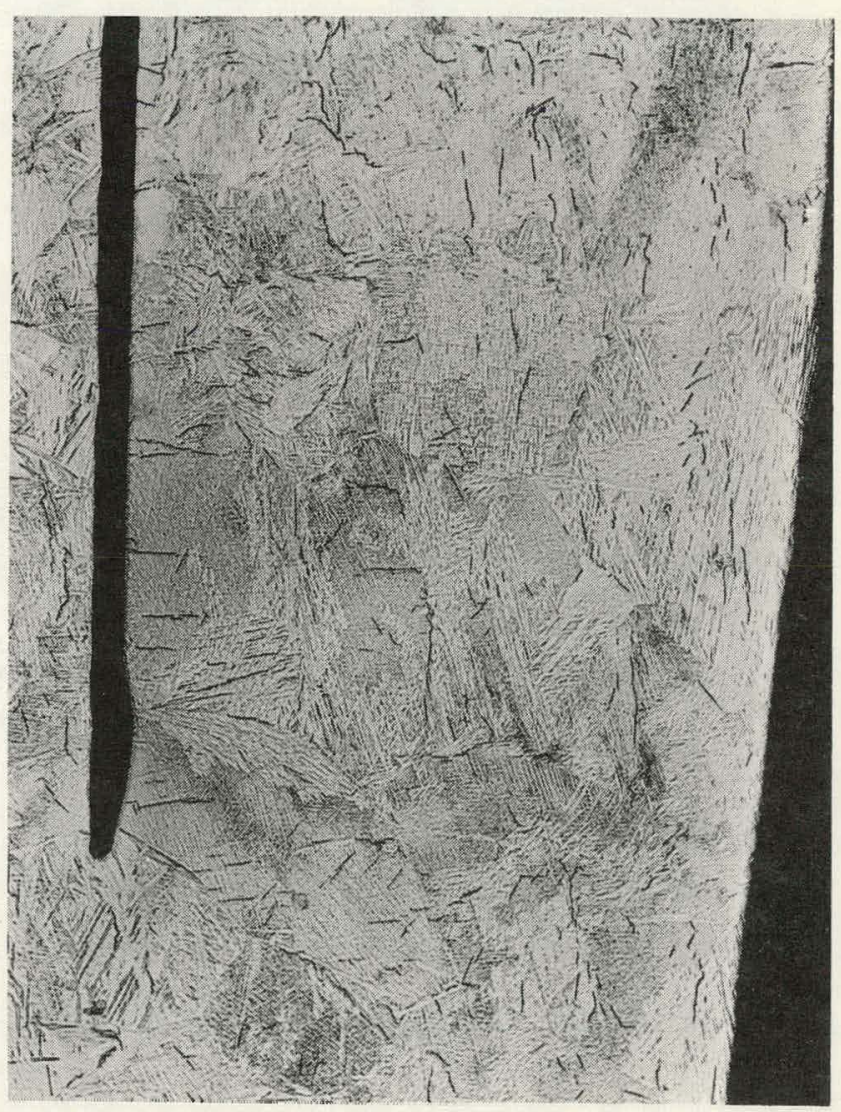

(d) Weld Region; 50 ppm $\mathrm{H}_{2}$ 

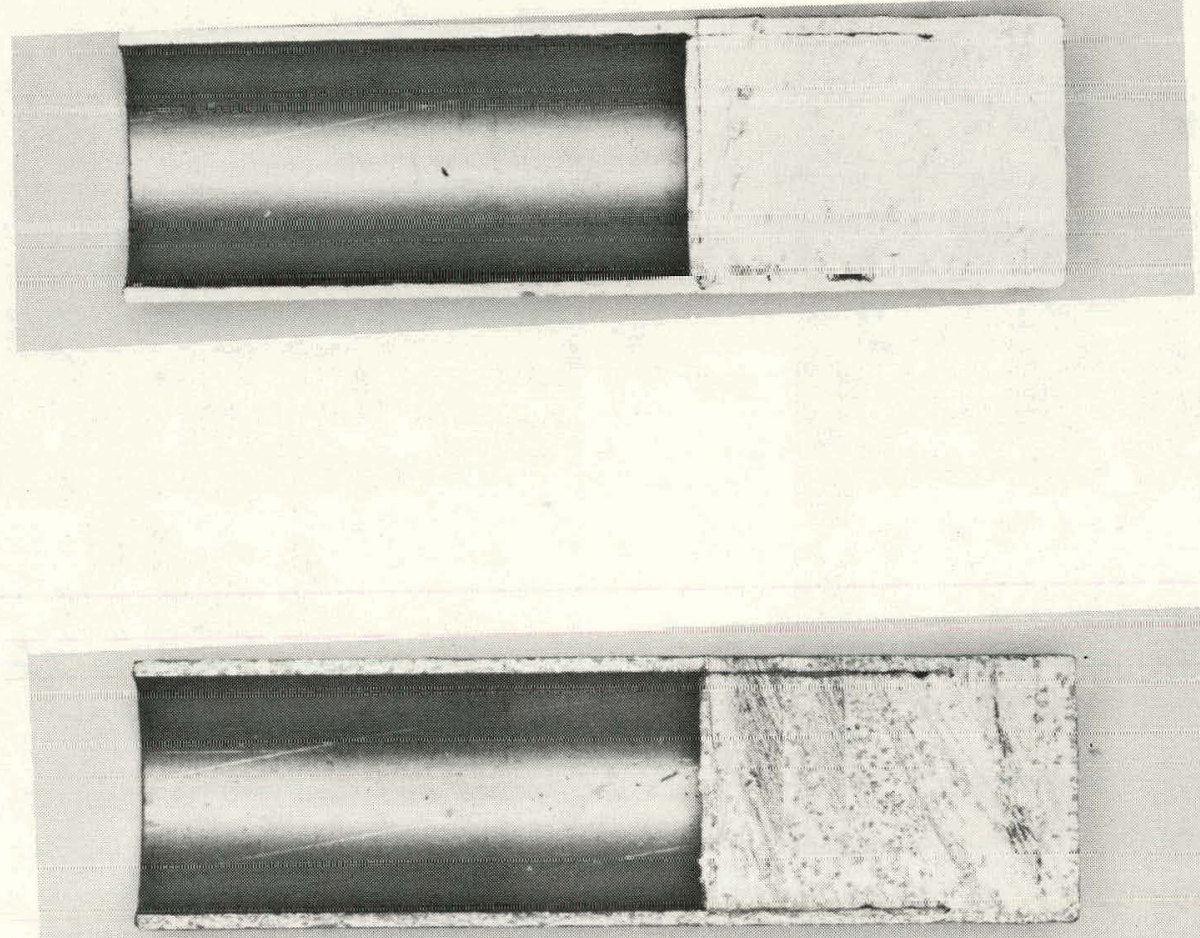

Figure 3. Sectioned Miniature Blanket Rods
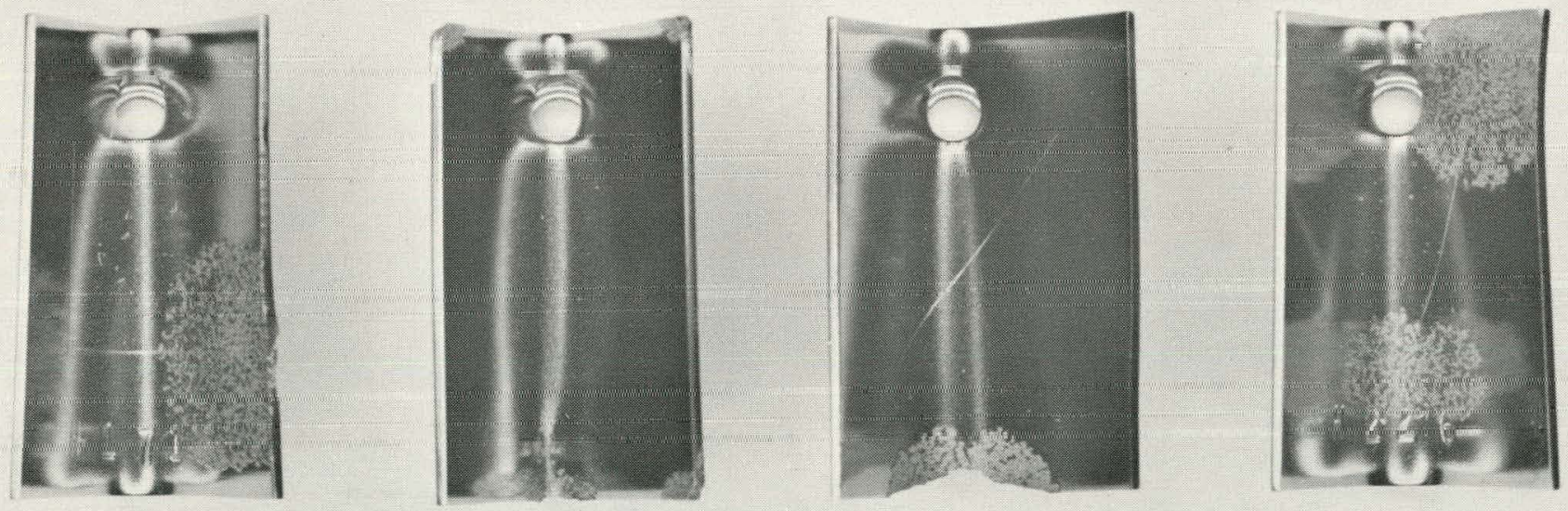

Figure 4. Scratched, Hydrided Curved Zircaloy Coupons 


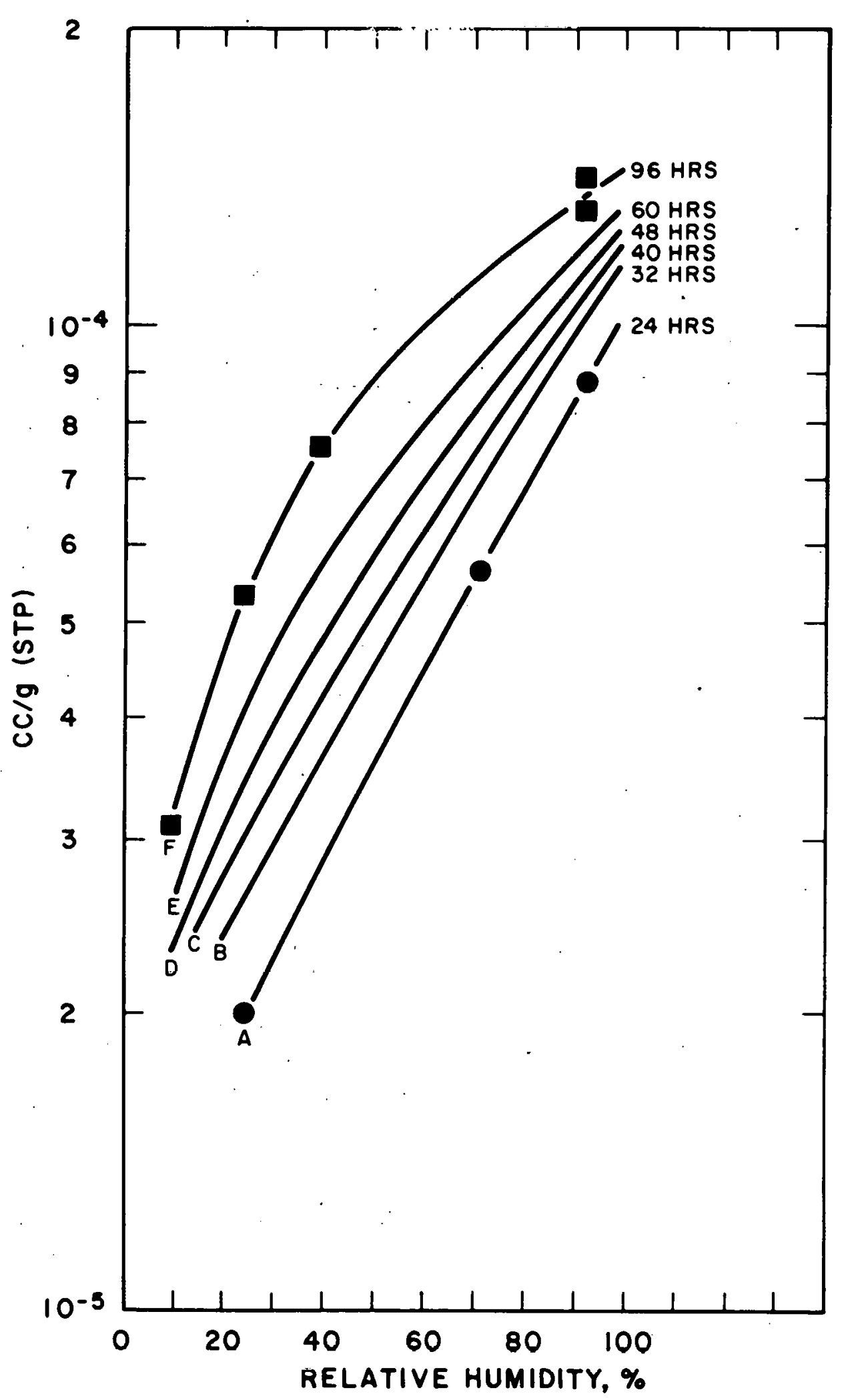

Figure 5. Moisture Content of $\mathrm{ThO}_{2}$ Reflector Pellets 
(REFERENCES $7,9,10$ )

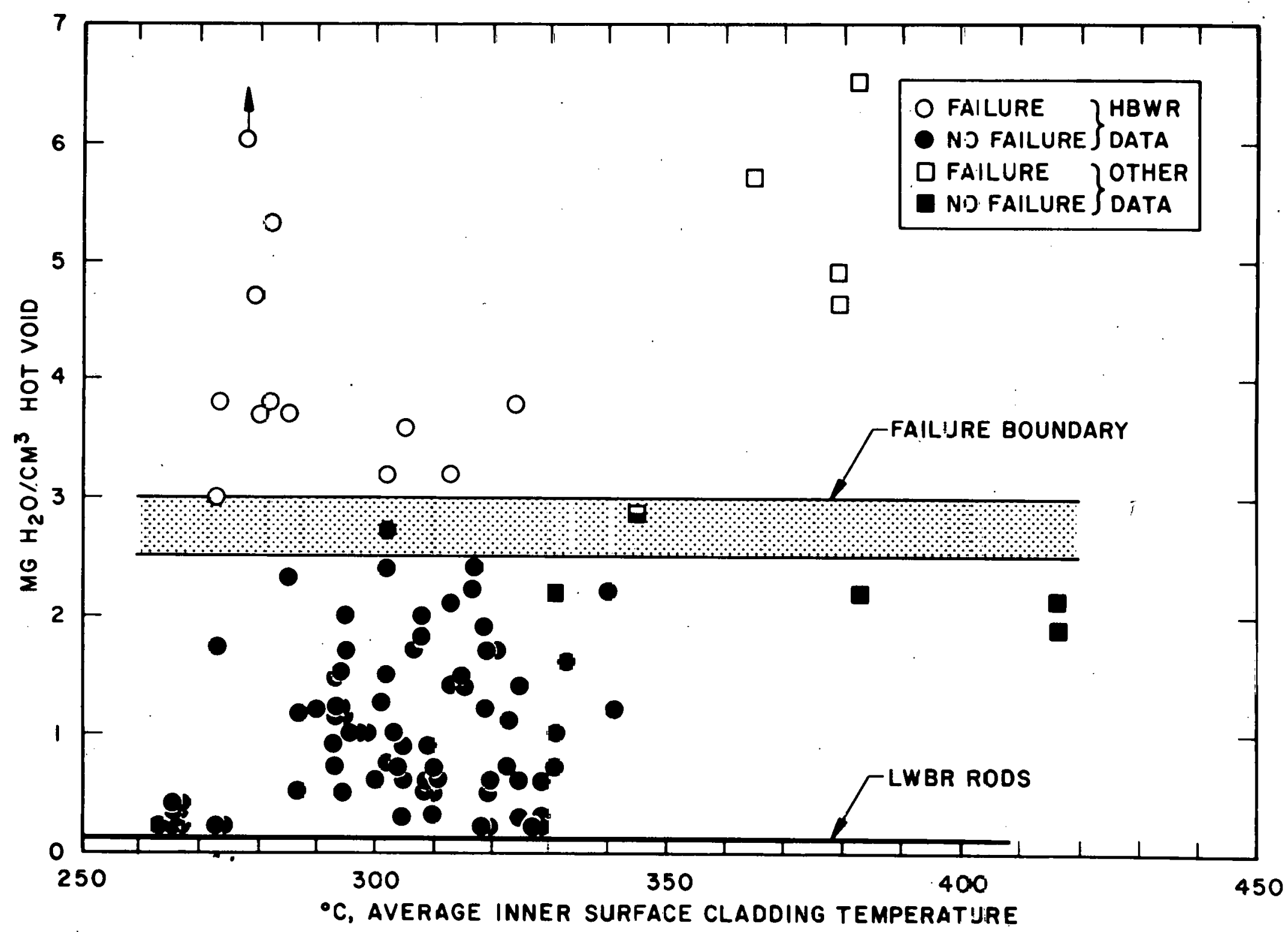

Figure 6. Internal Jydriding Failure Boundary $\varepsilon s$ a Function cf Moisture Concentration 